\title{
The Variability of the Vascular Supply to the Ureter
}

E. D. Varverikos, B.A. M.D.

\section{Anatomy}

TH E S S

Submitted in partial fulfilment of the requirement for the degree of Master of Science.

MCG111 University, Montreal, Canada. 
ACKNOWLEDGEMENTS:

The work presented in this thesis was done between 1950 and 1951 in the Department of Anatomy, Faculty of Medicine of McGill University. It is my great pleasure to express my thanks to Dr. C. P. Martin for giving me the opportunity to work under him in this Department, and to acknowledge my gratitude to him for directing and criticizing this work.

To Dr. A. D. Campbell, who throughout this period of study lent encouragement and constructive criticism, my sincere thanks.

To Dr. Elizabeth Virginia Lautsch, my gratefulness for tie translations of the German authors, Feltal, Frommolt, Protopopow and Wiebel.

For the photography and correlation of material, my thanks to Mrs. Phyllis Mawdsley.

For the typing of this thesis, my thanks to Miss Doreen Matthews.

Por making it possible for me to acquire material, other than that supplied by the Anatomy Department, I am grateful to the Royal Victoria Hospital and Herbert Reddy Memorial Hospital. 
TABLE OF CONTEMTS

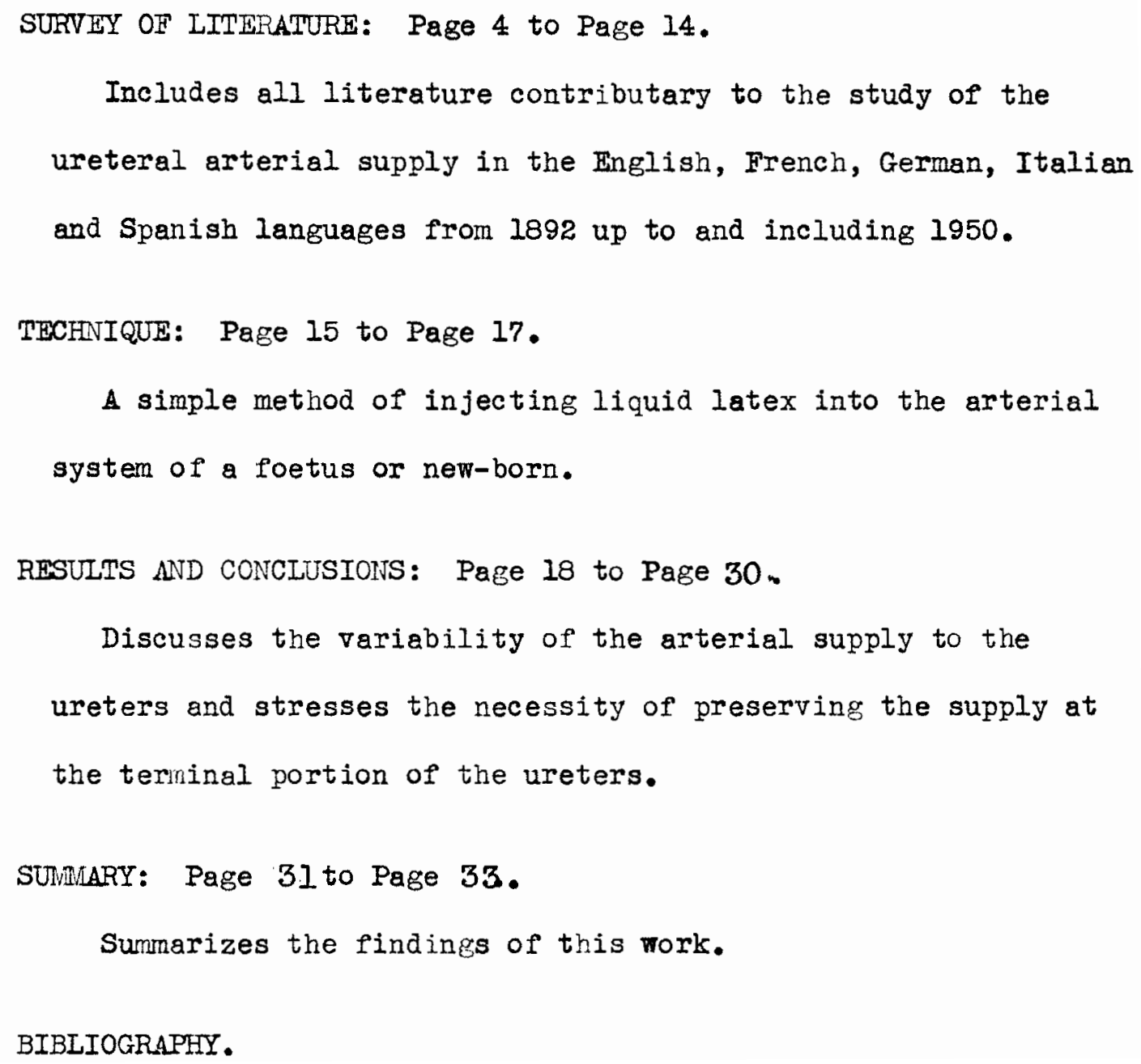




\section{INTRODUCTION}

This study of the arterial supply to the ureter was made because of the prevalence of injuries to the ureter in pelvic surgery and gynecologic complications to the ureter and kidney following pelvic intervention.

R. Brooke Bland of Philadelphia, reporting in the Medical Journal and Record of 1925 on surgical injuries to the ureter in pelvic operations, states that in 361 injurea cases the types of injuries were, listed in order of frequency: ligation, incision, excision and necrosis due to vaseular interference. Dr. Fred J. Taussig of st. Louis, in the American Journal of Obstetrics and Gynecology in 1934, writing on iliac lymphadenectomy with irradiation in the treatment of cancer of the cervix points out: That the size of a gland did not determine whether it had metastasis or not: that irradiation of the cervix did not alter lymph node metastatic growth: that glands involved in order of frequency were, iliac obdurator, ureteral and sacral, and from these the second stage group, lumbar aortic, inguinal and common iliac. Again in 1935 Taussig, in an article on the Removal of Lymphnodes in Cancer of the Cervix, points out that radium implantation is not satisfactory and stressed the importance of complete lymphadenectomy, especially the parametrial, ureteral, obdurator and iliac groups. It will be readily seen then how, following a panhysterectomy where an attempt has been made to clean out the lymph-node masses, it 
has often been noted that the ureter lies in the pelvis like a loose wire across a floor, and one can readily understand why the complications would involve the pelvic portion of the ureter. As radical surgery in the pelvic area becomes more and more important and a thorough cleansing of the pelvic glands more common, we note in the statistics that the first and most common complication is fistulas of ureteral origin, secondly necrosis and atrophy of the kidney of the ureter involved, and thirdly acute dilation of the ureter with retention.

Feeling therefore that damage to the vascular supply is the main factor in all complications following pelvic intervention, this study was undertaken in order to understand the variability of supply. I use the word "variability", for if one looks at our standard textbooks one comes to the conclusion that there is nothing actually definite. Gray's gives no explanation of the aterial tree. Cunningham refers to vessels that may come off in the abdominal portion from the renal or gonadic arteries, and in the pelvis from the vesicals or middle rectal arteries. I. Testut in Vol. 4, 7th edition, gives the best description: the calices and pelvis are supplied by branches from the renal; the abdominal and iliac portions of the ureter by the renal, gonadic, aortic and, or cormon, iliac; the pelvic portion by the internal iliac and by the vesical in the male or uterovaginal in the 
female. The intra-vesicular portion is also supplied by the arteries directly supplying the bladder.

Testut quotes Latarjet and Laroyenne who published a paper in Association Anatomique de Marseille in 1908 on Notes Anatomiques sur les Vaisseux de L'Uretere, - "From these main branches a very fine anastomic mesh of capillaries end in the superficial layer of the mucosa by forming a finer meshwork."

Obviously the textbooks do not supply sufficient information for comprehensive understanding of the problems involved in radical surgery in this area. 


\section{HISTORY}

The earliest and complete study of the ureteral blood supply was made by Dr. John A. Sampson of Johns Hopkins. In the Bulletin of Johns Hopkins Hospital of February 1904, Sampson quotes Quin's Anatomy, London, 1896,- "The ureter is supplied with blood from the small branches of the renal, spermatic, internal iliac and inferior vesical". He also quotes Morris in his paper of Surgical Diseases of the Kidney and Ureter, published in London in 1901,- "The arteries which supply the ureter are branches of the renal, spermatic, or ovarian and vesical, they anastomose freely together in the walls of the ureter and the blood is returned by corresponding veins". A third source found in Sampson's work is Van Barderben's Handbuck der Anatomie, where Gustav Fisher of Jena, in 1902 stated, - The ureteral vascular supply comes from many sources: in the abdomen, branches from the renal artery extend down over the abdominal portion of the ureter: the spermatic artery also furnishes the abdominal portion of the ureter: the spermatic artery also furnishes the abdominal portion of the ureter as it crosses this organ: the pelvic portion is supplied by the middle hemorrhoidal and interior vesical artery".

Sampson shows that the main arterial branches lie along the wall of the ureter and are held there by loose connective tissue. The 
large branches run longitudinally in the adventitia and give off branches which pierce the muscularis layer and go into the propria, there forming a mesh-like net. This capillary system extends from the propria in two directions, 1) to the epithelium, and 2) to the muscularis. The veins of the ureter begin in the propria and from this a veinous plexus is formed in the muscularis. A second and larger veinous plexus is formed in the adventitia. He also points out a peri-ureteral arterial plexus with branches utero-subperitonealy which have origin from the aorta, renal, gonadic, and iliac of uterine arteries. These main branches divide in two, one to the ureter and a second subperitoneal branch supplying the tissue near the ureter. Concerning the ureteral branches: these divide into ascending and descending branches attached to the ureter by loose fibrous tissue and anastomose freely with the other branches. Thus about the ureter there is a relatively large arterial trunk manning longitudinally from kidney to bladder. From this trunk smaller branches arise to form a freely anastomosing plexus in the perimuscular fibrous tissue, and small twigs from this perimuscular plexus leave the ureter and supply the tissue about the ureter. Sampson also states that the subperitoneal vessels supplying the tissue about the ureter and the peritoneium over this area may also anastomose with ureteral plexus branches and therefore help to 
supply the ureter. Branches from the uterine and vesical arteries of one side may anastomose with branches from the other side. In his experimental work with dogs, he showed that the larger blood vessels may in part be destroyed by stripping them off and if one so destroyed the superficial plexus the smaller deeper branches would take over. However, if these smaller branches are destroyed by scraping the wall of the ureter, necrosis follows, and if one ligates vessels to the ureter above and below a point to be stripped, necrosis follows. Veinous plexus injury must also embarass circulation to a degree varying with the extent of the injury. Sampson's conciusion from this is that the ureter could be dissected free from bladder to kidney if the peri-ureteral arterial plexus is not impaired. He quotes Mergorvicci and Monari who, in experimental work with dogs, isolated the ureter in its entire length and still had a perfectly viable ureter. But Protopopow in Butrage zur Anatomie und Physiologie der Ureterem, in 1897 calls attention to the fact that he is unable to show a similarity in blood supply to the ureter of dogs and man, and he does not know if such a dissection would leave a viable ureter in humans. Even so, Frammolt did experimental work with dogs and stated in 1927 that he was quite successful in that necrosis very seldom followed extensive dissection. However it is now established on the authority of several men, that the ureteral blood supply of man and dogs do not compare. 
Sampson goes on to quote Feital, who points out that the upper part of the pelvic portion of the ureter receives its blood supply from the medial side, e.g., from the aorta, the common and internal iliac vessels and the lower part from the vessels lateral to the ureter, e.g., the uterine and vesical arteries. In exposing the ureter, he advises that the upper part of the pelvic portion should be exposed by opening the peritoneum lateral to the ureter, carrying the incision across it at the middle of the pelvic portion and continuing down along the lower pelvic portion medial to the ureter. Thus he says, the nutrient vessels will not be injured.

In gross dissection Sampson speaks of a peri-ureteral sheath, and though his cross-gections of the abdominal portion did not show it, he says he can make it out riti a little imagination. This sheath is more definite ir the pelvis, and cross-sections here show a definite sheath ahout the ureter, which seems to be a thickening of the pelvic tissue through which the ureter plays. Such a section is shown in Sampson's article, where a definite ureteral sheath surrounding the ureter and peri-ureteral arterial plexus is evident. Toward the bladder, the ureter shows a reinforced muscular bundle. Waldeyer, in 1892, refers to this as arising from the bladder, but Disse in 1902 , states this reinforced muscular bundle to be hypertrophied sections of the ureter not related to the bladder. This peri-ureteral sheath is 
adherent to and partially derived from the structures about the ureter, therefore it is in close contact with the utero-vaginal and vesicalvaginal plexus of veins and if these are removed when the peri-ureteral sheath is pulled away from the ureter, necrosis will follow, and because the sheath takes partial origin from the ureter, the ureter will become fixed in scar tissue causing adhesions and therefore functional interference leading to partial or complete ureteral obstruction. This Sampson shows in dog experimentation where after sacrifice, the ureter was found to be dilated proximal to its point of imbedding in scar tissue.

Following Sampson's excellent work, W. J. Mayo, in Canada Lancet in 1907, states in The Surgery of the Ureter, that though he was taught that the ureter had only one blood ressel supplying it, he now felt it to be one of the best supplied organs in the body.

In 1927 a German by the name of Gunter Frommolt in Zeitschrift fur Geburtgchilife Und Gynakologie, in a paper Uber Die Artereilien Kollateralbanen Un Menschlichen Ureter, demonstrated that: the upper portion of the ureter is supplied by branches from the renal artery, the midale third by the ureteral artery proper, and the lower third by branches from the arteries to the urinary bladder and the uterine. By the ureteral arteries, Frommolt means the arteries which may come from the aorta, common iliac or internal iliac. He says that some authors 
mention a branch from the spermatic arterial plexus to the lower third of the ureter and the middle hermorrhoidal artery as also giving a branch.

Frommolt injected 43 individuals; new-born, children and adults, with 22 satisfactory results. These 44 ureters showed a total of 40 renal branches, in the four remaining cases he believed that two lacked branches due to imperfect injection and the other two were found to have branches from the capsular arterg. He found only three cases where branches came off the gonadic artery. The ureteral artery was found in every case, often as two or even three branches on either side. In the lower third he found branches from the superior vesical, was deferens, or the uterine in the fernale, and noted that the primary vessels prior to attaining the ureter break up into several branches going up and down in the adventitia. From these secondary branches he found tertiaries piercing the adventitia obliquely which all anastomose freely. Protopopow in 1897 and Disse in 1902 have already described these branches.

Frommolt injected natural red into the renals and ultramarine blue into the internal iliacs to demonstrate the anastomosis mentioned above. He ligatured the ureteral artery and then injected the aorta with red oxide of lead solution and by $x$-ray pictures 
showed adequate blood supply by other channels. Also the hypogastric or internal iliac was injected and showed anastomosis reaching up to the kidney. He concludes that cutting one or other of the vessels to the ureter will not cause damage. He also cut most of the longitudinal branches and injected a blue solution into the aorta and was able to demonstrate in one case adequate supply to the ureteral adventitia. However on further disection of the ureter he revealed a deeper vaseular network in the wall of the ureter and concluded that darage to the adventitia would cause necrosis of the ureter.

Cyril A.R. Nitch, in Proceedings of the Royal Society of Medicine of 1931, on the Transplantation of the Ureters into the Large Intestine, shows that failure of transplant was due to vascular supply impairment to the ureters. He points out that the pelvic portion of the ureter is supplied by the superior vesical and middle hemorrhoidal and that the supply varies in size, length and position. He states that Mr. A.I.P. Jeffery, demonstrator of Anatomy at St. Thomas Hospital has shown clearly that the gonadics do not give branches to the ureter below the pelvic brim. Dr. Nitch goes on to say that if the vascular supply is high off the pelvic brim the transplant will be good, but if the supply is low, near the bladder, it will be difficult to make a good transplant and when the supply is very low and must be cut, success is questionable. 
In the British Journal of Urology, 1942, W.F. Harper published a paper on the Observations on the Blood Supply of the Human Ureter. In his introduction he first points out that successful transplant is the result of an unaffected blood supply and that the vitality of the ureter must be maintained. To support this statement he quotes Nitch. Pointing out how the pelvic supply is variable in size, length and position of the ureteral branches from the superior vesical and middle rectal, he observes that then these vessels are coming of $f^{\circ}$ near the brim of the pelvis they can be preserved without difficulty, but it they come off near the base of the bladder the transplant is difficult and If sectioned the vitality of this portion of the ureter is impaired. Harper's personal observation from 10 foetuses and 12 adults after injection with india ink through the aorta of the fomer, and through the renal, testicular and vesicals of the latter, showed that the renal axtery supplied calyces, pelvis and the proximal segment of the ureter, end that their descending branches anastomosed freely with the ascending ureteric branches of the gonadic. (The present author wishes to note that when an accessory renal artery is present, this anastomosis is most marked). Anastomosis was noted freely in the extra-peritoneal tissues, renal fascia, adipose tissue and the supra renals. From the gonadic the branches come off both above and below it where it crosses the duct and these anastomose with the renal, accessory renal anc ureteric branches from the aorta, common iliac and superior vesical. In 
the pelvis the gonadic artery did not give any branches.

The aortic branches cone oft the anterior lateral aspect and $\varepsilon$ into the extra-peritoneal tissue over the psoas major and anastornose on the ureter with branches from the testicular, common iliac or superior vesical below. In the pelvis the chief source is from the vesical and middle rectal, and in the female from the uterine arteries. The inferior vesical artery branches anastomose with those of the superior vesical and middle rectal, the anastomosis with the middle rectal being constant. The middle rectal gives branches above the level of the spine of the ischium which pass via the adjacent retro-peritoneal tissue to the seminal vesicles, prostate gland, vas deferens or upper vagina. These primary branches form a dense and complex outer plexus in the adventitial connective tiasue. Microscopic study showed arterioles of 30 to $40 \mathrm{mu}$ passing from the adventitia through the muscularies and forming a finer plexus in the lamina propria, from which branches go to the muscularis. The lower segment of the ureter lies in an extra-peritoneal area richly vascularized by inferior vesical and midale rectal arteries.

Dr. Joe $\nabla$. Meigs in 1945 on the Nertheim operation for carcinoma of the cervix, in the American Jounnal of Obstetrics and Gynecology, quotes Dr. James $M$. Neil who pointed out an artery supplying the ureter just as the uterine artery goes over it, and since the uterine 
artery is sacrificed in these operations, it is important how and where it is sectioned. Meigs showed that ureteral fistulas were 12.3\% of the complications, and that these occurred around the upper part of the vagina where the ureter maises a groove on the wall of the ragina as it goes into the bladder.

The last published work in medical literature is by John P. Micheels, who in Surgery, Gynecology and Obstetrics Revue of 1948 showed a study of the ureteral blood supply and its bearing on necrosis of the ureter following the Werthelm operation. He points out that the ureter receives its chief blood supply from the major vessels along the route of the ureter, that is, renal, abdominal aorta and common iliac. The ureteral artery arises from these vessels running laterally to reach the medial side of the ureter where it divides into a $T$ with an ascending and a descending branch. These branches mun parallel to the ureter in the loose peri-ureteral areolar tissue and anastomose with similar branches above from the renal and gonadic and below with branches from the uterine and vaginal, inferior vesical and sometimes superior vesical and may anastomose with branches from the middle hemorrhoidal. These branches send smaller branches to supply the ureter in their immediate vicinity. He points out that the vessels in the abdomen reach the ureter on its medial side, while those in the pelvis, on its lateral aspect. Since the long ureteral branches ramify around and over the ureter, anastomosing with each other above and below and by 
secondary branches pierce the muscularis, any injury to the wall of the ureter will affect the secondary branches whereas the primary arteries are easily injured in the periphery of the ureter. From his charts he has concluded that the main blood supply to the ureter may be multiple, the source being either the abdominal aorta, common iliac or a combination of these. The main supply may therefore be endangered in Preeing the ureter through its pelvic source or during pelvic lymphadenectomy. The ureteral branches from the renal uterine and vesicals, while constant are but short branches. These however play an important part in the peri-ureteral anastomosis. Ureteral branches from the internal spermatic (or ovarian) are inconstant and are generally small twigs.

In surveying the literature to determine whether the plexus of arteries in the musculature of the ureter could nourish the ureter it the peri ureteral arterial plexus were damanged or stripped off, the concensus of opinion still holds with Sampson who stated, "one would suppose that the destruction of the periureteral arterial plexus for only a short distance would lead to necrosis of the ureter, for even if there should be a free anastomosis of the deep arteries of the ureter, on account of their size and small numbers, one would not suppose that they would be capable of maintaining the nourishment of the ureter for any great distance". Many others have contributed to the medical literature on the ureters, but have not been mentioned here because their work did not bear directly on the problem involved in the present author's work. 


\begin{tabular}{|c|c|c|c|c|c|c|c|c|c|c|}
\hline \multicolumn{11}{|c|}{ FOETUS 6 MONTHS AND UNDER } \\
\hline - & S. & R. & G. & A. & C.I. & I.I. & $\mathrm{U}_{\bullet}$ & SUP. V. & INF. V. & P.D.I.I. \\
\hline \multirow[t]{2}{*}{ MALE } & PII & - & - & & - & & & - & - & \\
\hline & IT & - & - & & - & $\cdot$ & & - & - & \\
\hline \multirow[t]{2}{*}{ MALE } & $\underline{\mathrm{R}}$ & - & & & - & & & - & - & \\
\hline & $\bar{L}$ & $=$ & - & & & - & & - & & \\
\hline \multirow[t]{2}{*}{ FEMALE } & $\underline{\mathbf{R}}$ & - & - & & - & & - & & & \\
\hline & $\bar{I}$ & - & - & & & & $\overline{-}$ & & & \\
\hline \multirow[t]{2}{*}{ MALE } & $\underline{R}$ & - & & & - & & & - & & \\
\hline & $\mathrm{L}$ & - & & - & - & & & - & & \\
\hline \multirow{2}{*}{ MAIE } & $\mathbf{R}$ & - & & - & - & - & & & - & \\
\hline & I & $=$ & & - & $=$ & - & & & - & \\
\hline \multirow{2}{*}{$4 \frac{1}{2} F$} & $\underline{R}$ & - & - & & - & $=$ & - & & & \\
\hline & $\bar{I}$ & - & - & & & $=$ & $=$ & & & $=$ \\
\hline \multirow[t]{2}{*}{$4 \mathrm{H}$} & $\underline{\mathbf{R}}$ & - & - & & & - & & - & & - \\
\hline & $\mathrm{I}$ & - & $=$ & & - & & & - & & - \\
\hline \multirow[t]{3}{*}{$4 M$} & $\underline{\mathbf{R}}$ & - & - & & & - & & & - & \\
\hline & $\overline{\mathrm{I}}$ & - & & & $=$ & $=$ & & & - & \\
\hline & & $\begin{array}{l}\text { G. } \\
\text { S. } \\
\text { R. } \\
\text { G. } \\
\text { A. } \\
\text { C.I. }\end{array}$ & & $-\infty$ & $\begin{array}{l}\text { Side } \\
\text { Renal } \\
\text { Gonadic } \\
\text { Abdomen } \\
\text { C. Iliac }\end{array}$ & & & $\begin{array}{l}\text { I.I. } \\
\text { U. } \\
\text { SUP. VES. } \\
\text { MD. VES. } \\
\text { INH. VES. } \\
\text { P.D.I.I. }\end{array}$ & $\begin{array}{l}- \text { Hypog. Int. } \\
-- \text { Uterine } \\
-- \text { Sup. Vesical } \\
-- \text { MD. Vesical } \\
-- \text { Inf. Vesical } \\
-- \text { Post Division }\end{array}$ & Internal I \\
\hline
\end{tabular}




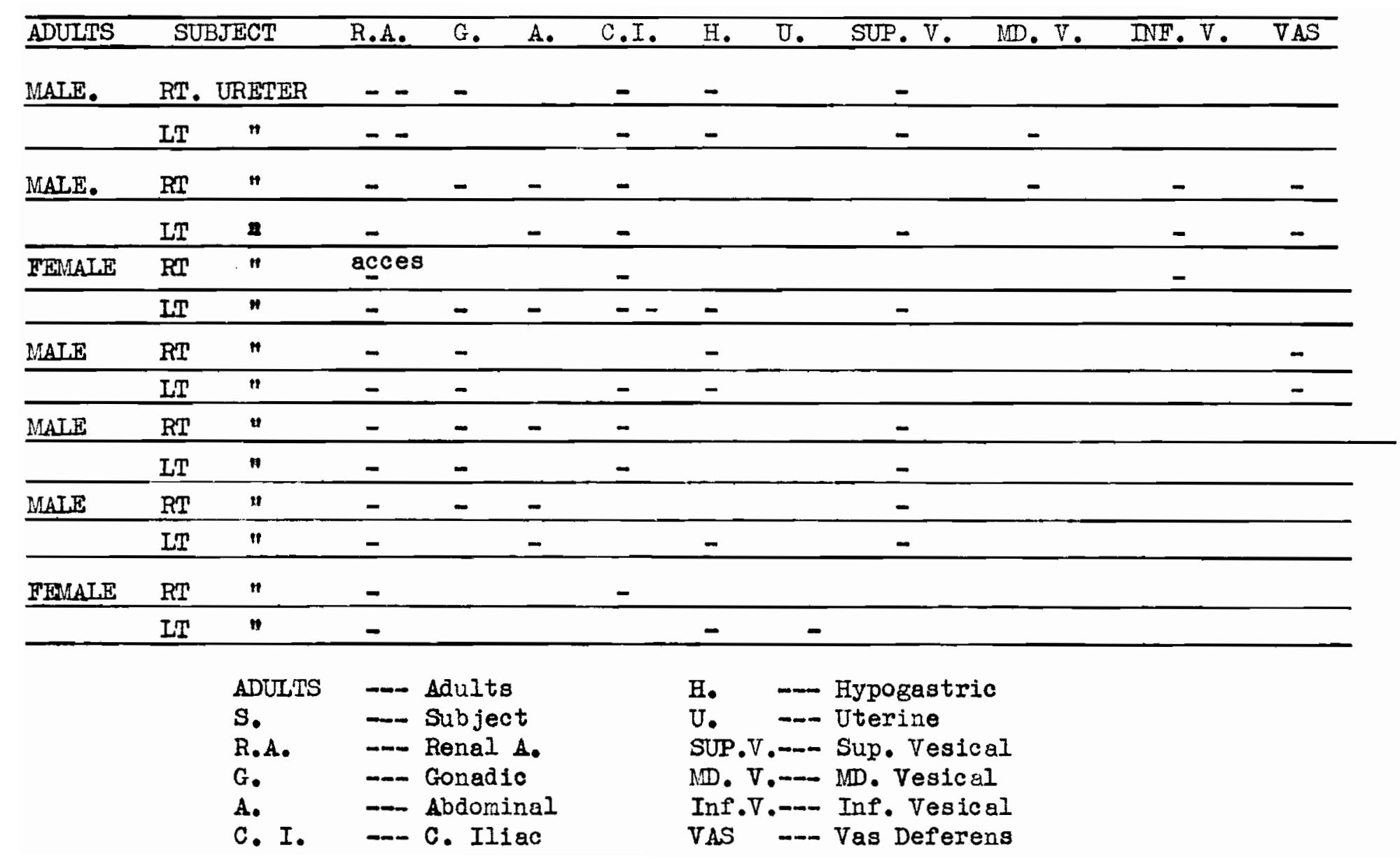


NEW-BORNS

\begin{tabular}{|c|c|c|c|c|c|c|c|c|c|c|c|c|c|}
\hline . & S. & R. & G. & A. & C.I. & I.I. & U. & SUP. V. & $M D, V$. & VAS. & I. VES. & M. SACRAL & P.D.I.I. \\
\hline \multirow[t]{2}{*}{ MAIE } & $\underline{\mathbf{R}}$ & - & - & - & - & - & & - & & - & & & - \\
\hline & I & - & $=$ & - & $=$ & $=$ & & $=$ & & $=$ & & & - \\
\hline \multirow[t]{2}{*}{ FEMAIE } & $\underline{\mathbf{R}}$ & & & & & - & - & & & & - & - & \\
\hline & $\bar{L}$ & $?$ & & & - & - & $\overline{-}$ & & & & - & & \\
\hline \multirow[t]{2}{*}{ FHMALE } & $\underline{\mathrm{R}}$ & - & & - & & & $=$ & & & & - & & \\
\hline & $\overline{\mathrm{L}}$ & - & & -- & & $=$ & $=$ & & & & - & & \\
\hline \multirow[t]{2}{*}{ FEMAALT } & $\mathrm{R}$ & - & & $=$ & - & & - & & & & - & & \\
\hline & $\mathrm{I}$ & - & & & - & - & - & & & & - & & \\
\hline \multirow[t]{2}{*}{ MALE } & $\underline{\mathrm{R}}$ & - & & & ext - & - & & $=$ & & - & - & & - \\
\hline & $\overline{\mathrm{L}}$ & - & & & - & - & & - & & - & - & & - \\
\hline \multirow[t]{2}{*}{ FIMALE } & $\underline{\mathrm{R}}$ & - & - & - & - & - & - & & & & & & \\
\hline & $\overline{\mathrm{L}}$ & $=$ & - & - & - & - & - & & & & & & \\
\hline \multirow[t]{2}{*}{ MAIE } & $\underline{\mathbf{R}}$ & - & & - & & - & & - & & - & - & & \\
\hline & $\bar{L}$ & $=$ & & - & & - & & - & & - & $=$ & & \\
\hline \multirow[t]{2}{*}{ MAIE } & $\mathbf{R}$ & - & & - & & & & & & - & - & & - \\
\hline & $\bar{L}$ & - & & - & & - & & & & $=$ & $\overline{-}$ & & - \\
\hline \multirow[t]{2}{*}{ MAJE } & $\underline{\mathbf{R}}$ & - & - & -- & & - & & & & - & - & & - \\
\hline & $\bar{L}$ & - & & - & $=$ & - & & & & - & - & & $=$ \\
\hline \multirow[t]{2}{*}{ MALE } & $\underline{\mathrm{R}}$ & - & & & - & & & & & - & - & & - \\
\hline & L & - & & - & & & & & & $=$ & $=$ & & $=$ \\
\hline $\begin{array}{l}\text { S. } \\
\text { R. } \\
\text { G. }\end{array}$ & & $\begin{array}{l}\text { Side } \\
\text { Renal } \\
\text { Gonadi }\end{array}$ & & $\begin{array}{l}\text { A. } \\
\text { C.I. } \\
\text { I.I. } \\
\text { U. }\end{array}$ & $\begin{array}{l}\text { Abdc } \\
\text { C. I } \\
\text { Hypc } \\
\text { Uter }\end{array}$ & $\begin{array}{l}\text { nen } \\
\text { liac } \\
g \text { Int. } \\
\text { ine }\end{array}$ & & $\begin{array}{l}\text { Sup. V. } \\
\text { MD. V. } \\
\text { VAS } \\
\text { I. VES. }\end{array}$ & $\begin{array}{l}\text { Sup. V } \\
\text { Ma. Ve } \\
\text { Vas De } \\
\text { Inf. V }\end{array}$ & $\begin{array}{l}\text { sical } \\
\text { ical } \\
\text { erens } \\
\text { sical }\end{array}$ & & $\begin{array}{l}\text { ACRAL } \\
\text { I.I. }\end{array}$ & $\begin{array}{l}\text { Sacral } \\
\text { t Division } \\
\text { ternal Iliac }\end{array}$ \\
\hline
\end{tabular}


THE ARTERIAL SUPPLY TO THE URETER

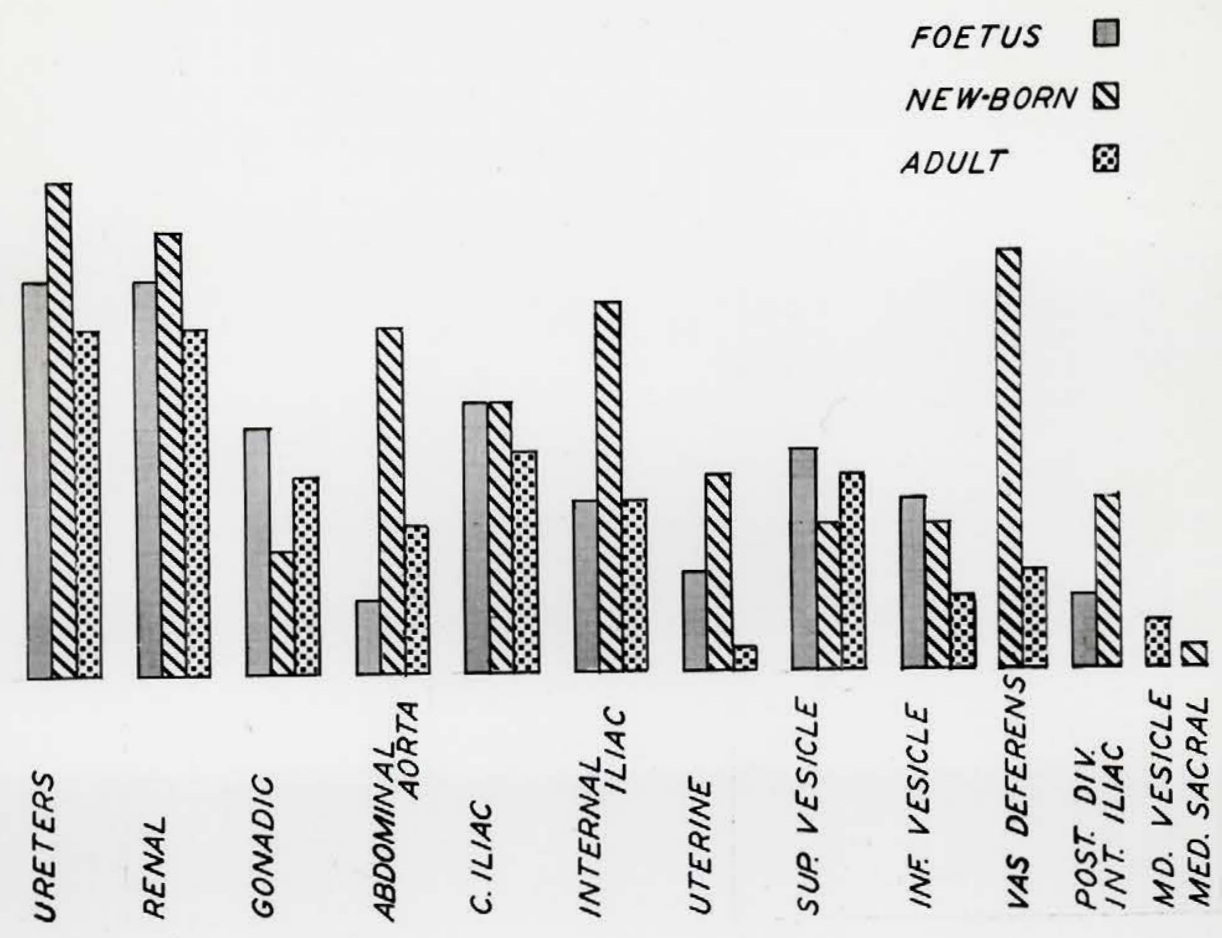

Composite chart

1. For charts of foetus, new born and adultis.

2. Note number of ureters dissected in extreme left column.

3. Remaining columns denotes arterial supply. 


\section{TECHNIQUE}

The method developed by Ethel Lieb for injecting the arterial tree was first tried, with only fair results. The method developed by Narat, Loef and Narat required equipment which was not available. Also this method seemed to hold the possibility of mupture of some of the vessels, and the disadvantage of clearing the veinous system as well as the arteries so that injected material would fill the veins and make them indistinguishable from the arteries. Gamble's method proved to have some of the same disadvantages. The method finally used was extremely simple and entirely effective.

When an autopsy was required in the case of a new-born specimen, injection had to be made prior to the autopsy and with as little damage as possible. Permission was obtained to go into the thoracic cage, tie off the pulmonary hilum and cut out the lung to get at the thoracic aorta. The aorta contained blood which was squeezed out. A glass cannula was then inserted into the aorta and tied in place with two sutures around the aorta. Next a slit was made in the abdominal wall so that a small loop of intestine was visible. Then with a rubber plunger syringe an injection with 20 to $40 \mathrm{cc}$ 's of red pigmented latex was made into the aorta by way of the cannula. Pressure and amount of latex was judged by vatching the vessels on the loop of intestine protruding from the slit in the abdominal wall. 
When these arteries were completely injected, the cannula was removed and the aorta tied off. When the Pathology Denartment was interested in the case, the particular organ of interest was disected out, taking care that, as much as possible, the retroperitoneal system of the posterior abdominal wall was left intact. The remainder of the specimen was then put in the refrigerator for 24 hours, in which time the latex had set. After eliminating the abdominal viscera, the urogenital system was removed en bloc, down from the diaphragm and with the terminal portion of the sigmoid and rectum. This portion of the bowel was later dissected out of the bloc. A rectangular frame was then made from a glass rod and the specimen sutured to it: through the kidney laterally, the aorta above and the bladder below. The specimen was then fixed in a mild solution of formalin, or in later specimens, Kisserling 1, in order to preserve the color.

The above method was so entirely successful that it was used on all foetal and new-born specimens from the time its trial proved it effective.

Dissecting out of the vascular tree was done under water in a glass pie plate wich, when placed on a Keleket X-Ray view box, allowed light to penetrate from below. A magnifying glass with a light on a stand provided light from above, and the vessels were carefully traced to the ureters, genitilia, bladder and peritoneum covering these. 
The adult specimens: 5 male and 2 female: were Department of Anatomy material and had already been impregnated with a preserving mixture of acid, aldehyde and alcohol. These specimens were injected with a red lead mixture, but it was felt that all the vessels miknt not have been completely injectea, and the possibility of error was such that adult dissection was soon discontinued. 


\section{RESUTTS}

The arterial supply of the ureters of adults, new-borns and foetuses was studied with the following questions in mind:

1. Are any of the arteries constant, and if so what are their characteristics with regard to the ureteral segment supplied, position, and direction of vessels?.

2. Are some of the vessels inconstant, and if so what are their characteristics with regard to length of ureteral segment supplied and size of vessel?

3. How closely is the vascular supply of the ureter associated with that of the peritoneum covering it?

It was always born in mind that due to blockage of a vessel, injection might not have been complete. Therefore the following data may in some measure be in error, however it is felt that the observations made are as correct as is reasonably possible.

A study of the adult chart shows that the only constant artery to the ureter was from the renal artery. This supply may be from a single branch or occasionally from two branches. It may come off the renal prior to that artery reaching the kidney pelvis, or after it has reached the pelvis. If it comes off in the kidney pelvis the branch is found on and adherent to the adventitia of the hilum. The branch may run down on the anterior or the posterior aspect of the 
ureter, and if there are two branches, one runs anteriorly and one posteriorly.

All the remaining arteries to the ureter found in the adult group were inconstant as shown in the chart, though branches from the common iliac and gonadic arteries were more nearly constant than the others. The comparatively few branches shown from the uterine, vesical and vas arteries gives, it is believed, a misleading picture and is attributed to the pre-injection embalming of the bodies which apparently caused constriction of these small vessels, so precluding the red lead mixture.

Due to the above mentioned constriction of the smaller vessels it was not possible to observe anastomosis of any of these vessels. It is also obvious that under the above mentioned conditions no observations as to the importance of inconstant vessels can be made. In the renal area the ureteral branches were not adherent to the peritoneum in any of the seven specimens, but rather were found to be imbedded in the peri-renal fat tissue. Below this area and more particularly at the terminal portion of the ureters, the vessels were found to be adherent to the retro-peritoneal areolar tissue. In the peri-ureteral sheath, which is a condensation and thickening of the areolar tissue around the ureter, branches of the vesical and uterine or vas arteries form a peri-uretheral plexus. 
In the new-born and foetal specimens the branch from the renal artery was found to be nearly constant, being absent in only one specimen. This supply may be single or double (figure 1). It may come off the renal artery or the accessory renal, before or after these arteries enter the kidney pelvis (figure 2). A branch may come off one of the hilar branches or it may come off a peri-renal branch after it enters the peri-renal fat tissue, where it may send a branch to the ureter and one to the hilum. The branches may run anterior or posterior to the ureter and if there is more than one branch they may run both anterior and posterior to the ureter. If the kidney has an additional supply near its inferior pole this extra artery may give off a branch to the ureter posterior to it. In a few cases in the adult specimens this showed up well. If it is present this vessel is usually small, about half the size of the vessels usually found supplying this portion of the ureter.

In general, the upper third of the ureter is supplied by one or two relatively large branches from the renal artery, but it may be supplied entirely by many small branches from the other sources mentioned. The branches from the renal artery rarely send out anastomotic branches to the arterial tree of the peri-renal fat and fascia, though they run through, and are supported by this perirenal tissue. Branches from the renal artery do not generally run 
down the ureter below the upper third of this organ, and they lie in areolar tissue adhering to the adventitia of the ureter, where they send twig-like branches to the muscularis (figure 2).

Branches from the abdominal aorta, present in $46 \%$ of the cases, are most often bilateral (figures $2,3 \& 4$ ). They are often small branches and run laterally in the retro-peritoneal areolar tissue. They throw off branches to the peritoneum which anastomose freely, forming a vascular plexus with anastomotic branches from the gonadic and other abdominal branches and branches coming down from the renal capsule. They may even cross and anastomose with branches from the other side (figure 3). Occasionally a branch arises at the bifurcation of the aorta into the cominon iliacs. As a rule this source will innediately divide into many tentacle-like branches which will supply both ureters fron this single source (figure 5). The abdominal aortic branches always approach the ureter from the medial aspect and split into upward and downward branches running along the medial side of the ureter where they lie loosely in the areolar tissue on the adventitia. The upward running branch may anastomose with a branch from the gonadic artery which, if present, comes off its parent vessel as this crosses the ureter on a more superficial plane. (figure 3). These branches from the gonadic artery were found contributing to the supply to the ureters in $48 \%$ of the cases, and it 
Was noted, as stated by previous writers, that these branches did not run down below the pelvic brim.

'Whe largest branch supplying the ureter comes off the common or internal iliac arteries (figure 6). The constancy of this branch was found to be about $60 \%$ to $65 \%$, and it cones off the medial aspect of the iliac, curves laterally over the parent vessel and approaches the medial side of the ureter. It throws off small branches in the areolar tissue on which it lies, ihereby making it adherent to the peritoneum (figure 3). Prior to reaching the ureter this primary branch divides into secondary branches, one running upwards and one downwards in the areolar tissue close to the adventitia of the ureter, and as a rule the upward branch is larger than the downward one (figure 7 ). These seconary branchos lie loosely in the areolar tissue and are often rather tortuous (ficure 8). They throw off branches to the peritoneum and thereby help to anchor the ureter to the peritoneum. It may be significant that in the one case where no renal branch to the ureter was found, the upward secondary branch from the iliac artery supplied the ureter up to the hilum (figure 1). When branches from both the common and internal iliac arteries were found supplying a single ureter, it was noted that they were usualy smaller than when a branch from one or the other was present alone, and that their supply to the ureter tended to be less extensive, both upward anc downward 
along the ureters.

Only one ureter was found that was not supplied by a branch from the aorta, common iliac or internal iliac arteries. All other ureters had some source of supply from these arteries. Three ureters were supplied by a branch from the aorta only; seven by a branch from the common iliac only; and five from the intermal iliac only. One third of the ureters were supplied by branches from two sources; a branch from the aorta and one from the internal iliac or occasionally the common lliac being the most frequent combination, but nearly as often a branch from each of the iliac arteries. Approximately one fifth of the ureters were supplied from all three sources.

The supply to the lower or terminal portion of the ureter is mainly dependent on the sex of the specimen. If female the supply :ill be from the uterine artery (figure 5) and was found to be constant in this sex; if male, the supply will be from the inferior vesical artery and sometimes from the vas artery, but branches from these sources were not found to be constant. There may also be an aditional branch from the internal iliac artery, such as the middle hemorrhoidal, and the downward secondary branch from the conmon or internal iliac has been found at this level (figures 9 and 6 ), but in one third of the female specimens the supply was found to be solely from the uterine artery. The branches from the arteries supplying 
the genitalia are very small (figure 10) but form a highly important plexus in the peri-ureteral sheath at the terminal portion of the ureter (figure 1l).

It should be specially noted that the branches to the terminal portion of the ureters from the arteries supplying the genitalia always reach the ureters frorn the lateral side and give off brailches either anterior or posterior to this organ (figures 5,12 and 13 ). The branches from the uterine artery are very adherent to the ureter, as is the parent vessei as it crosses the ureter, and the branches run upward and downward (figure 10). If a supply is coming from the posterior division of the internal iliac it reaches the ureter on its posterior aspect, and if the downward secondary branch from the common or internal iliac branch is present it runs medial to the ureter. Very rarely a branch will come down from the external iliac to this portion of the ureter.

Occasionally, as in Figure 5; a female foetus at term; it is observed that the arterial supply to the abdominal portion of the ureters is from a single surce. One exceedingly small branch from the renal artery was noted as supplying only the pelvis of the ureter. The terminal portion of the ureter, as may be seen in Figures 5 and 10, was supplied by the uterine artery as it crosses the ureter; where it gives upward and downward branches wich adhere closely to the ureter; and also at the pre-vesical portion of the ureter by branches 
from the inferior vesical artery. The abdominal and most of the pelvic portion of the ureters are wholely supplied by a single source which arises at the bifurcation of the aorta. This branch inmediately divides into several tentacle-like branches which, crossing the common and, or, internal iliac arteries in upward, lateral and downWarc directions, reach their destinations on the adventitia of the medial aspect of both ureters. All these tentacle-like branches are sub-peritoneal. They adhere moderately closely to the peritoneum along their courses, and at their terminations are rather loosely applied to the adventitia of the ureters where they branch into numerous smaller arterioles which form a lace-like mesh which anastomoses freely throughout the length of the ureters. The above mentioned specimer is considered to have adecuate arterial supply to the ureters, but the relatively limited supply to the peri-ureteral peritoneal plexus at the teminal portion would make the conservation of the branches from the uterine artery imperative.

Sometimes as in Figure 6 , a male new-born, the stroncest source of arterial supply is from the internal iliac arteries. The pelvis and upper portion of the ureters are supplied by sruall branches from the renal arteries; reenforced on the right by branches from the right gonadic artery and on the left by branches from the inferior medenteric artery as they anastomose witi arteries in the peritoneum overlying the ureter. The terminal portions of the ureters are supplied by small 
branches from the vas arteries as these cross the ureters, but the strongest supply in this area is from the descending branches from the main internal iliac sources, which originating on the medial aspect of the internal iliac arteries curve tortuously over their parent stems and run laterally on the peritoneurn to which they adhere by senaing arterial tendrils to the peritoneum. On reaching the medial aspect of the ureters these main branches divide, sending, strong ascending and descending branches along the adventitia of the ureters, where they give off long finger-like anastomotic branches to form a plexus with the vessels supplying the upper end of the ureters and downward to anastonose with tlose from the vas deferens artery •

It is important here to note the fine arterial plexus orer the front of the bladder which is so clearly shom in Figures 6 and 13. This plexus is formed of anastomotic branches from the Vas arteries of both sides, and since these Vas arteries also send branches to the terminal portions of the ureters, it is quite possible that the ras artery of one side may be able to supply the terminal portion of the ureter of the other side if the peritoneum covering the biadder is left intact.

The pattern of arterial supply to the ureters most commonly found is illustrated in Figure 4. The sources of supply are regularly 
spaced; the branches are all of approximately the same caliber and smaller than those in specimens with fewer branches; and the area supplied by each branch is the section of ureter nearest the source of supply. Each ureter receives a branch from the renal artery and the gonadic arteries give a branch each to the ureter of its own side. The porta sends a branch to each ureter and the common or the internal iliac sends a branch to the ureter nearest it. The terminal portions are supplied by branches from the vas arteries and the pre-vesical section by branches from the inferior vesical arteries.

This general pattern varies slightly. Sometimes the gortic branches arise nigher on the gorta than shown in Figure 4, and sometimes the aortic branches may be replaced by branches coming off the common fliacs just below the bifureation of the aorta. The source of supply from the internal iliac arteries usually arises just below the bifurcation of the common iliacs and occasionally, as seen in Figure 4, an iliac branch may divide alnost at its source and send two branches to the same ureter.

It should be pointed out however, that this cormonly found, regular pattern of supply does not necessarily mean that the terninal portions of the ureters in these cases are always more richly supplied from above than in the cases of relative scarcity of abdominal sources; for the strong downward secondary branch from the primary branch from a 
solitary abdominal source may, by its larger caliber, create a richer plexus about the terminal portion of the ureter.

Rarely a speciman such as the male new-born shown in Figures 3 and 13 is found. Here the multiplicity of primary branches and their overlapping loosely ramifying secondary branches are remarkable not only for their numbers, but also for the fact that they are of the larger caliber vessels usually found only in specimens with few primary branches.

The arterial supply to the upper part of the ureters is from the renal and accessory renal arteries; the latter may be seen very clearly at the left of the photographs as it runs a parallel course with the gonadic artery. The gonadic arteries give branches that are both larger in caliber and more extensive in area supplied than is usual with branches from these arteries. Subperitoneally branches arise from the aorta. The branches from the common iliac arteries show two unusual features; their coirse tends to be more downwards than is usual in this area and from the left common iliac there are two strong secondary branches funning cownwards on the adventitia of the ureter. Branches from the internal iliac arteries are not readily seen in the photograph as they arise at a lower level on the parent arteries than is usual and are hidden by the ureters. The terminal portion of the ureters are very rich $\perp$ y supplied by the vas and inferior 
vesical arteries as well as being abundantly reenforced by the descending branches from both the common and internal iliac sources.

Extreme variability of arterial supply is most marked in the abdominal portion of the ureter. Reference to the chart for foetuses of siz months and under will show the paucity of supply that may be found in this region as illustrated by the female six month foetus, and at the other extreme is the specimen mentioned above and illustrated by Figures 3 and 13 .

We can deduce from this that the main arterial supply to the terminal portion of the ureters is from the arteries supplying the genitalia, but that the supply may be multiple. That the supply is mainly from the lateral side but may ve medial and posterior as well. That the vessels are very small, even smaller than those supplying the upper third of the ureter, and that the relative poverty of supply to the lower portion of the ureter in a high percentage of the cases makes it imperative that the supply be maintained.

In conclusion, it is felt that the arterial supply to the ureters is so variable that it may be said thare is no constant supply, with the exception of the branches from the uterine artery in the female. That there are many inconstant branches and that there are branches of limited importance, but the importance of 
these branches varies so greatly from case to case, that no branch can be said to be unimportant per se. That in view of the fact that it was found that one-third of all the ureters in the female specimens were supplied at the terminal portion solely by the uterine artery; it is strongly felt that in perfoming a Wertheim pan-hysterectomy the uterine artery should always be cut medial to the ureter, and because the uterine artery as it crosses the ureter and its branches to the ureter are so acherent to this organ, it should never be necessary to strip them off and care shoula be taken always to preserve them. 


\section{SURIARY}

Fifty ureters were dissected following liquid latex injection of the areterial tree, and the sources of vascular supply were studied with special emphasis on distribution to the various parts of the ureters and the adjacent peritoneum.

The upper third of the ureters were found in all but one case to be supplied by branches from the renal artery. In the one case where there was no branch from this source, the upper secondary branch from the common iliac supplied the ureter up to the hilum. No evidence was found that the branches from the renal artery sent anastomotic branches to the peritoneum.

The gonadic arteries sent branches to the ureters in $48 \%$ of the 50 ureters, and these branches sent anastomotic branches to the peritoneum. It was noted that the gonadic branches never went below the pelvic brim.

Branches from the abdominal aorta averaged $46 \%$ of all the ureters. They were usually bilateral branches, but occasionally several branches supplied both ureters from one source. They sent out more anastomotic branches to the peritoneum than any other branches; except those from the common and internal iliacs; richly supplying the peritoneum and even anastomosing with branches from their opposite sides. 
When branches from both the common and internal iliacs were found supplying a single ureter, it was noted that they were usually smaller than when a branch from one or the other was present alone, and that their supply to the ureters tended to be less extensive, both upward and downward along the ureters.

The common iliacs sent branches to 62 percent of the total ureters and the internal iliacs to $63.9 \%$ of the ureters in the foetal and newborn specimens. When one of these lliac branches alone supply a ureter it has a characteristically large primary branch, with strong secondary branches which run well up the upper third of the ureter and may run as far down as the terminal portion. All the lliac branches richly supply the peritoneum and anastomose freely with anastonotic branches from other sources.

At the terminal portion of all the ureters of the foetal and new born specimens a periureteral peritoneal plexus was noted and the branches from the arteries aupplying this region were adherent to the peritoneum where it forms the periureteral sheath.

In the female new-born and foetal specimens, the uterine artery sent branches to $100 \%$ of the ureters. (Conditions for injection do not make possible figures for the two adult specimens.) It is of great importance to note that one third of all the terminal portions of the ureters in the females had no source of supply other 
than from the uterine artery.

In the male specimens, the superior vesical artery supplied $50 \%$ of the ureters, and the vas arteries $60 \%$.

The inferior vesical artery sent branches to $25 \%$ of the total new-born and foetal specimens, and the posterior division of the internal iliac sent branches to $35 \%$ of the ureters of these two groups.

The branches from the vesical and vas arteries richly supply the peritoneum over the bladder and commonly anastomose across the bladder.

In conclusion, it is felt that the vascular supply to the ureters is so variable that it can be said there is no constant supply, with the exception of the branches from the uterine artery in females. That there are many inconstant branches and that there are branches of limited importance, but the importance of these branches varies so greatly from case to case, that no branch can be said to be unimportant per se. That in view of the fact that it was found that one third of all ureters In the female specimens were supplied at the terminal portion solely by the uterine artery; it is strongly felt that in performing a Wertheim pan-hysterectomy the uterine artery should always be cut medial to the ureter, and because the uterine artery as it crosses the ureter and its branches to the ureter are so adherent to this organ, it should never be necessary to strip them off and care should be taken alvays to preserve them. 


\section{BIBLIOGRAPHY}

1) Bland, B.P. Surgical Injuries of the ureter. Med. J. Rec. 4, 1, 1925.

2) Cunningham. Textbook of Anatomy. 8th Ed, p. 707, Prof. C. P. Martin Ed. J.C. Brash \& E.B. Jamieson.

3) Disse, Van Bardelebem. Handbuch der Anatomie. Gustav Fisher. Jene 1902, Band 7, Thiel 1, s. 110-111.

4) Frommolt, G. Uber die arterielleu Kollateralbahren un menschlichen ureter. Zschr. Geburtsh. Gyn. 91, 205, 1927.

5) Gamble, D.I. Iiquid latex an injecting mass for blood vessels. Science Rev. 90, p. 518, 12-1, 1939.

6) Gray, Description and Applied Anatomy. 29th Ed, Johnston T.B. \& Whillis, J.

7) Harper, W.F. Observations on the blood supply of the hunan ureter. Br. J. Urol. 14, 63, 1942.

8) Jeffery, A.L.P. Demonstrator of Anatomy at St. Thomas Hosp. Cited by Nitch, Cyril, A.R.

9) Latarjet et Laroyenne. Association des Anatomistes. Notes Anatomiques sur le vaisseux de l'uretere. 1908.

10) Lieb, E. J. Tech. Met. $20,48,1940$.

11) Mayo, W.J. Surgery of the Kidney \& Ureter. Canada Lancet, 40, Sept. 1940.

12) Meigs, J.F. Joffe, H.L. Ca of Cervix treated by Roentgen - Ray and Radium. Am. J. Obst. Gyn. 69, \#3, Sept, 1939.

13) Meigs, J.V. Carcinoma of the Cervix. N.E.J.M. 230, \#19, 577, 1944.

14) Meigs, J.V. Ca Cervix - Wertheim Operation for Ca of the Cervix. Am. J. Obst. Gyn. 49, 542, 1945.

15) Meigs, J.V. Ca Cervix - Wertheim Operation. Surg. Gyn. Obst. 78, \#2, 195, 1944. 
16) Michaels, J.P. Study of the ureteral blood supply \& its bearing on necrosis of the ureter following the Wertheim operation. Surg. Gyn. Obst. 86, 36, 1948.

12) Margorvicci, Monari. Cited by Sampson. J.A. Bull. John. Hop. Hosp. p. 39, Peb, 1904.

18) Morris. Surgical diseases of the kidney \& ureter. London Lancet. V. 2, 1500, 1901. Cited by Sampson, J.A. (Book Review)

19) Narat, J.K. Loeff, J.A. Narat, M. A. Rec. 64, 155, 1936.

20) Nitch, C.A.R. Transplantation of the ureters into the large intestine. Proc. R. S. Med. 25, pt. 2, 1412, 1931.

21) Poirier, Charpy, Cueneo. Abrege d'anatomie. V. 3, Publ. 1909.

22) Protopopor, Butrage zur Anatomie und. Physiologie der ureterum. (Pflugers) 66, 21, 1897.

23) Quain, Quains Anatomy. V. 3, Pat 4, p. 205, 1896.

24) Sampson, J.A. The efficiency of periureteral arterial plexus \& the importance of its preservation in the more radical operations for $\mathrm{Ca}$ Cervices uteri. Johns. Hop. Hosp. Bull. p 39, Feb, 1904.

25) Taussig, J.E. Iliac lymphadenectomy with irradiation in the treatment of cancer of the cervix. Am. J. Obst. Gyn. 28, 650, 1934.

26) Testut, L. Textbook of Anatomy. 7th Ed, p. 453.

27) Taussig, J.E. The removal of Lymph Nodes in Cancer of the Cervix. Am. J. Obst. Gyn. 34, \#3, Sept, 1935.

28) Teibel, W. Zbl Gyn. 56, 2637, 1932. 


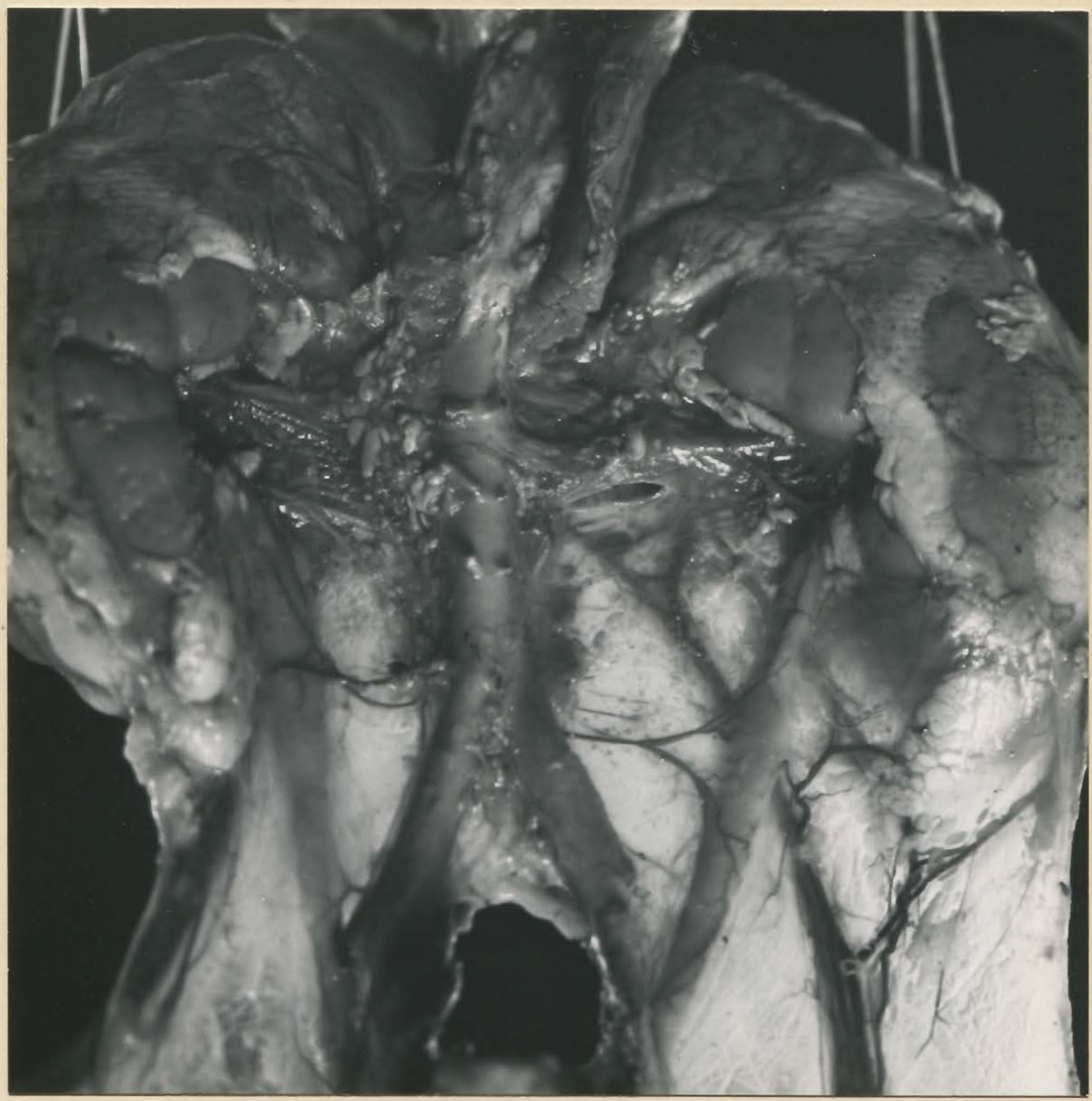

Figure 1. - Male, new-born, posterior aspect. Note renal branch and branches to the ureters arising before renal artery reaches the kidney pelvis. Note upward secondary branch from the internal iliac branch extending up to the hilum. 


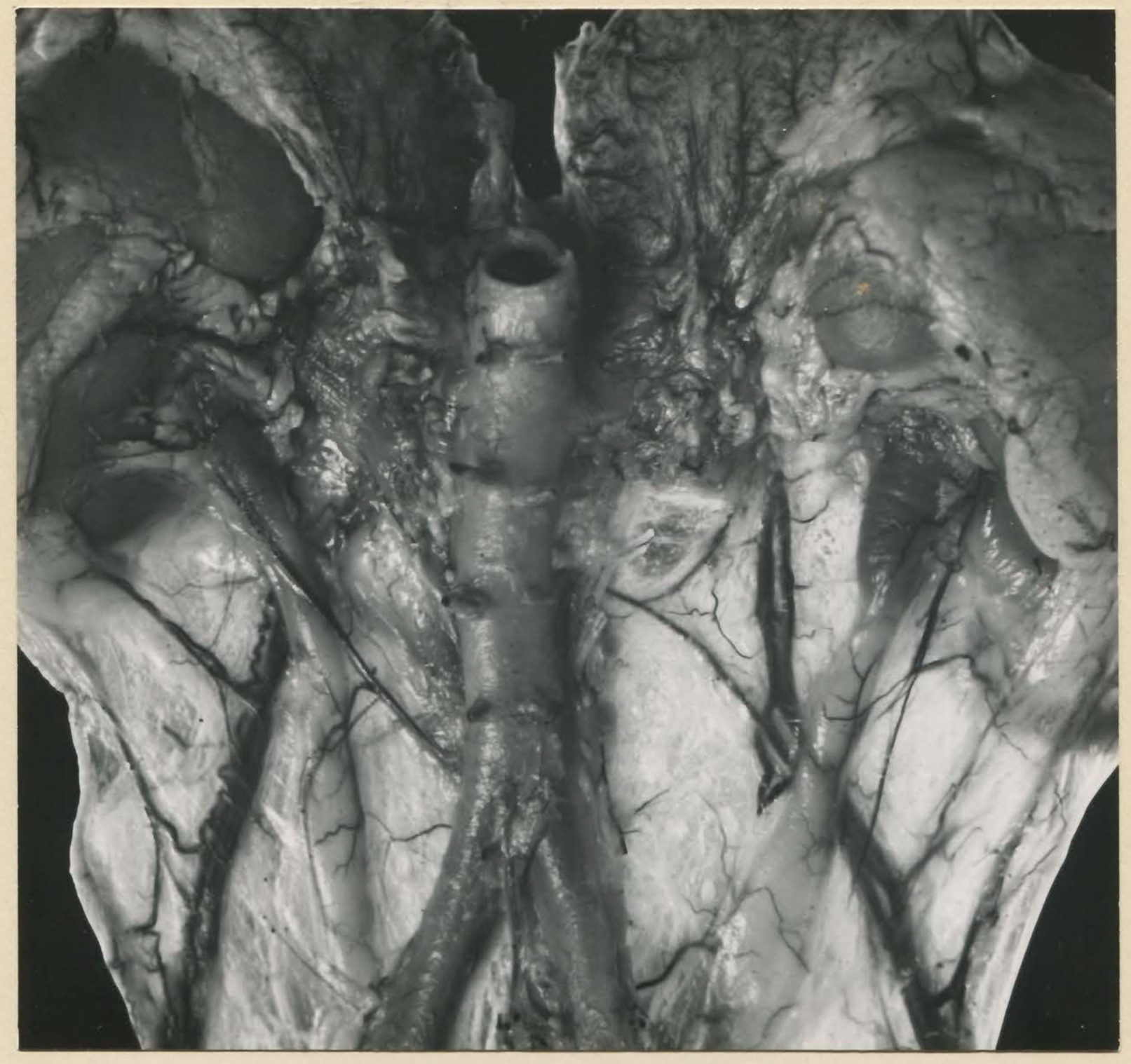

Figure 2. - Male, new-born, posterior aspect. Note branches from renal artery after it has entered the kidney pelvis. Note that the branches from the renal artery do not run down below upper third of ureter. 


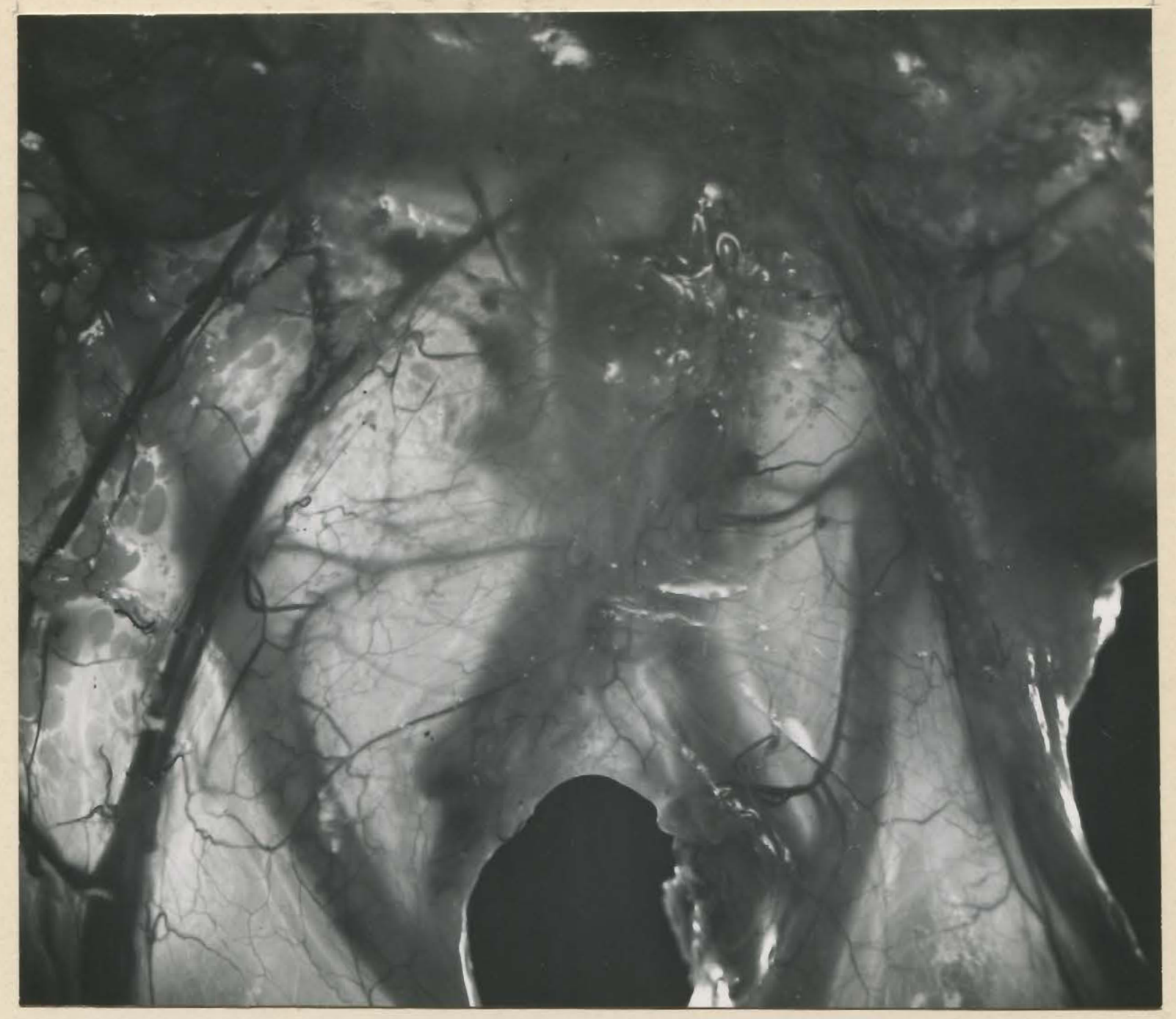

Figure 3. - Male. new-born, anterior aspect. Note bilateral branches from the abdominal aorta and branches from the common iliacs. Note extensive anastomosis in peritoneum. Note branches from the gonadic arteries. 


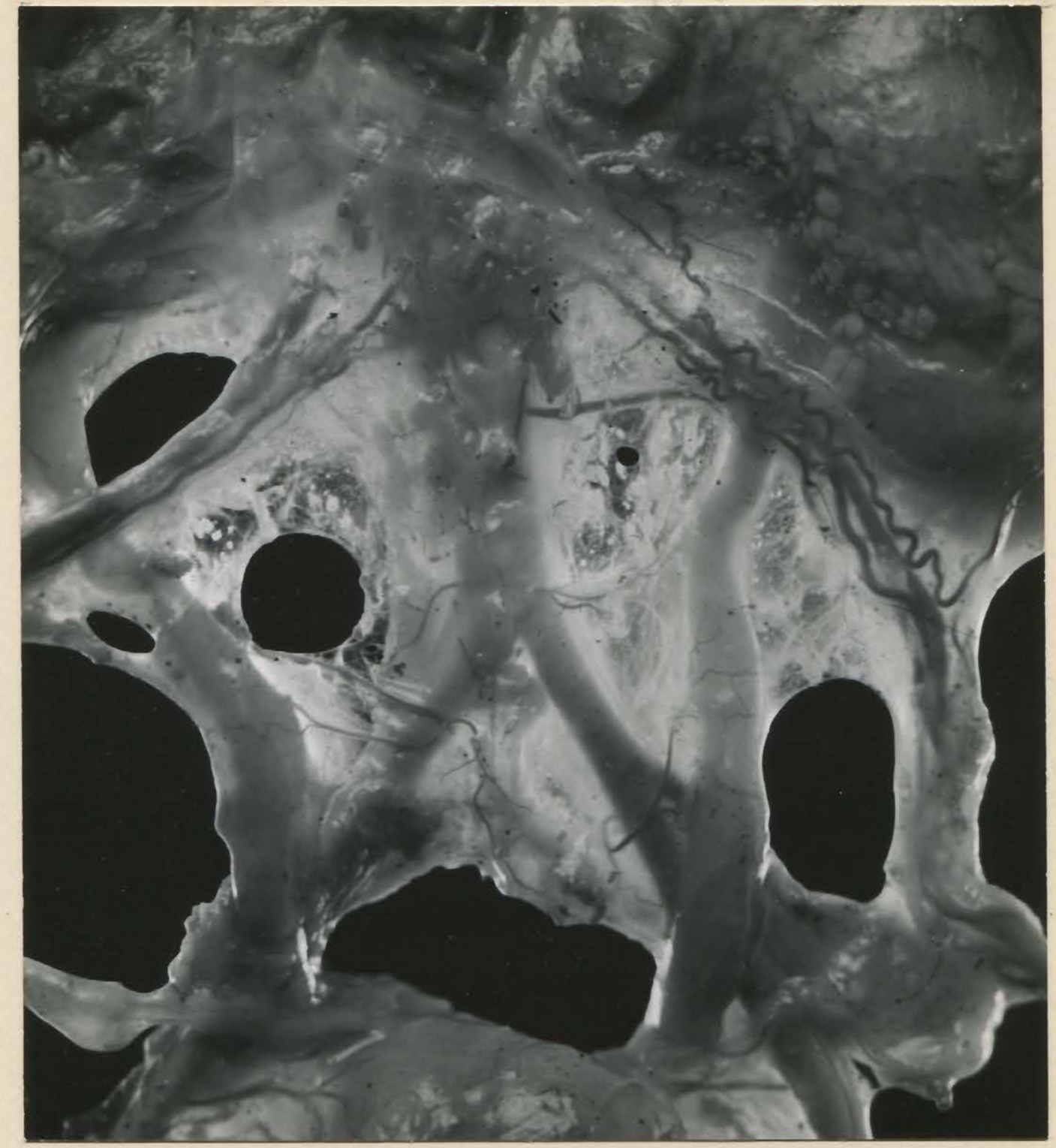

Figure 4. - Male, foetus, anterior aspect. Note bilateral branches from the abdominal aorta and branches from the common and internal iliacs. Note each branch supplies limited segment when supply is multiple. 


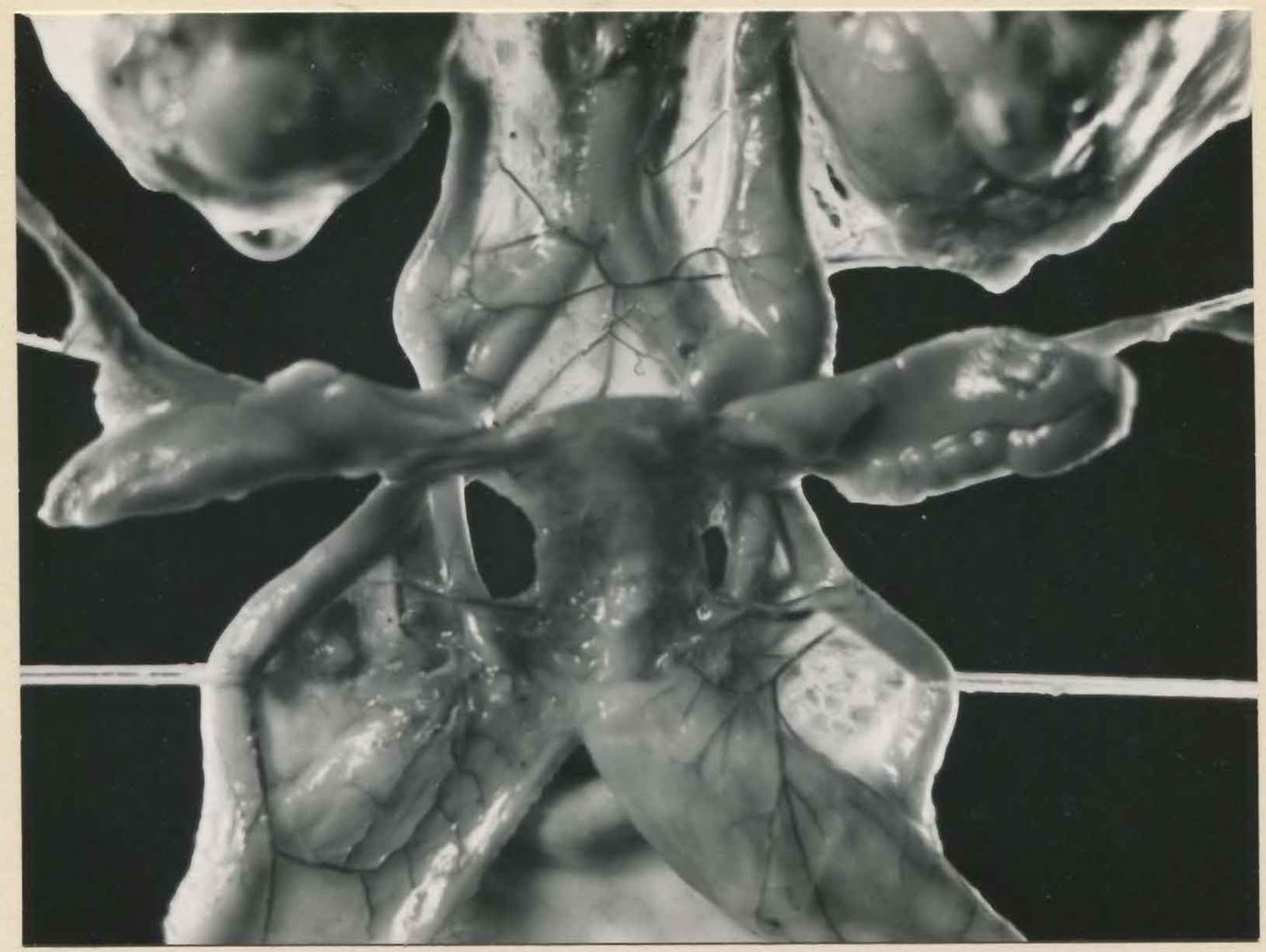

Figure 5. - Female, foetus, anterior aspect. Note multiple branches from single source at bifurcation of aorta. Note uterine artery giving branches to ureter on lateral anterior aspect. 


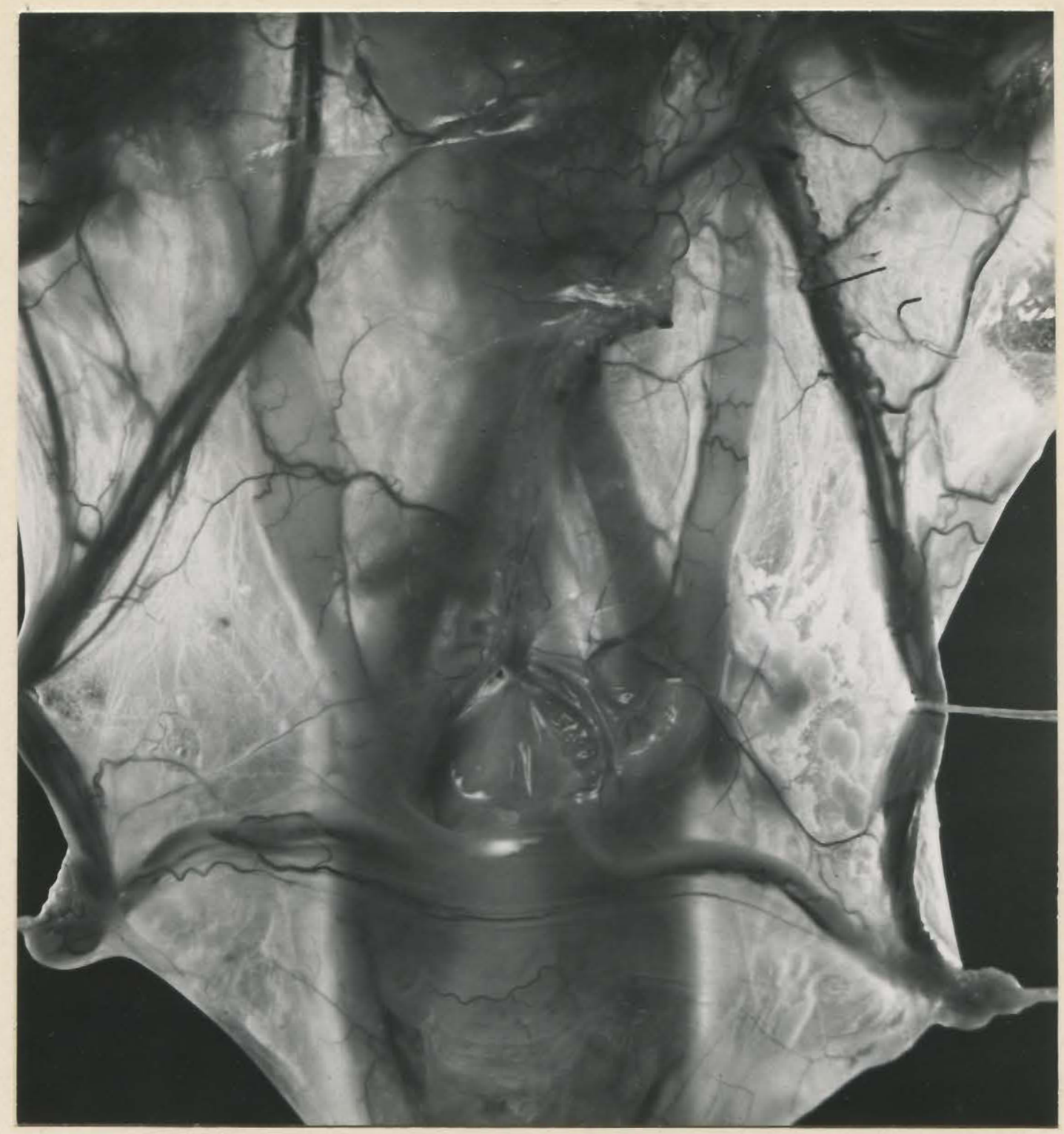

Figure 6. - Male, new-born, anterior aspect. Note branches from internal iliac arteries. Note branch from internal iliac supplying terminal portion of ureter. Note anastomosis in peritoneum and in inferior mesenteric area and across bladder. 


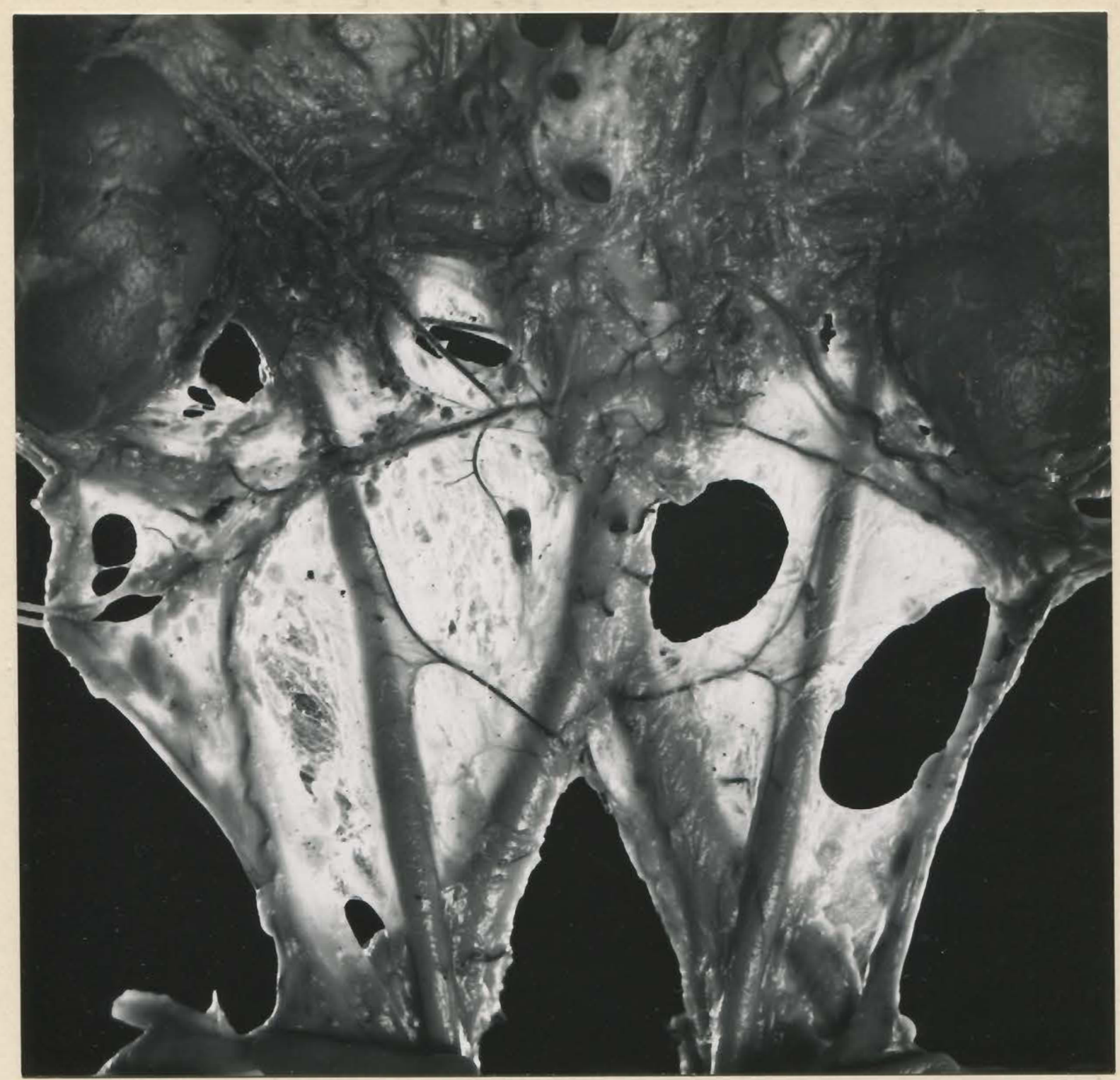

Figure 7. - Female, foetus, anterior aspect. Note larger upward running secondary branch from internal and common iliac branches. 


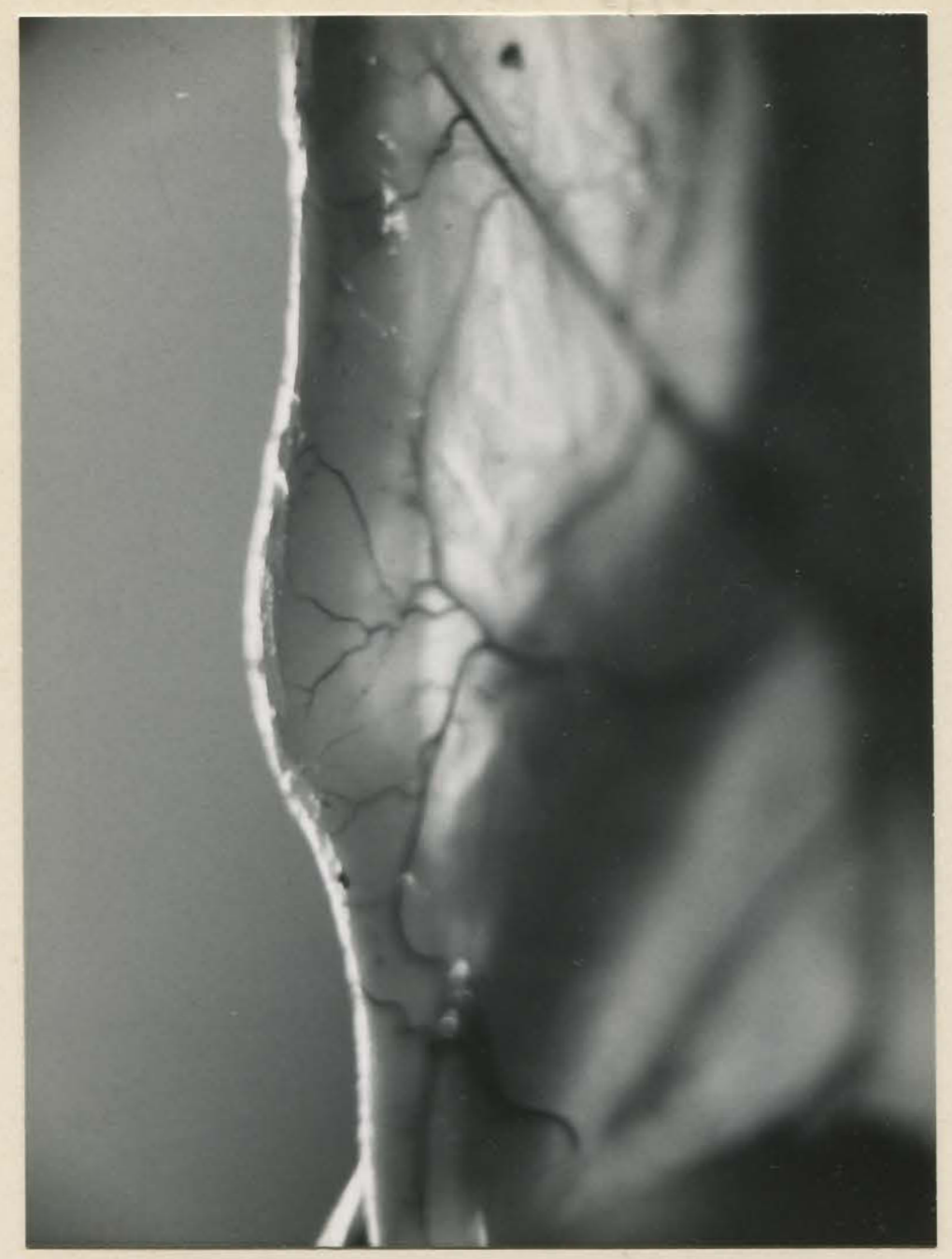

Figure 8. - Female, foetus, anterior aspect. Note secondary branches lying loosely in areolar tissue with twig-like tertiaries more adherent to adventitia. 


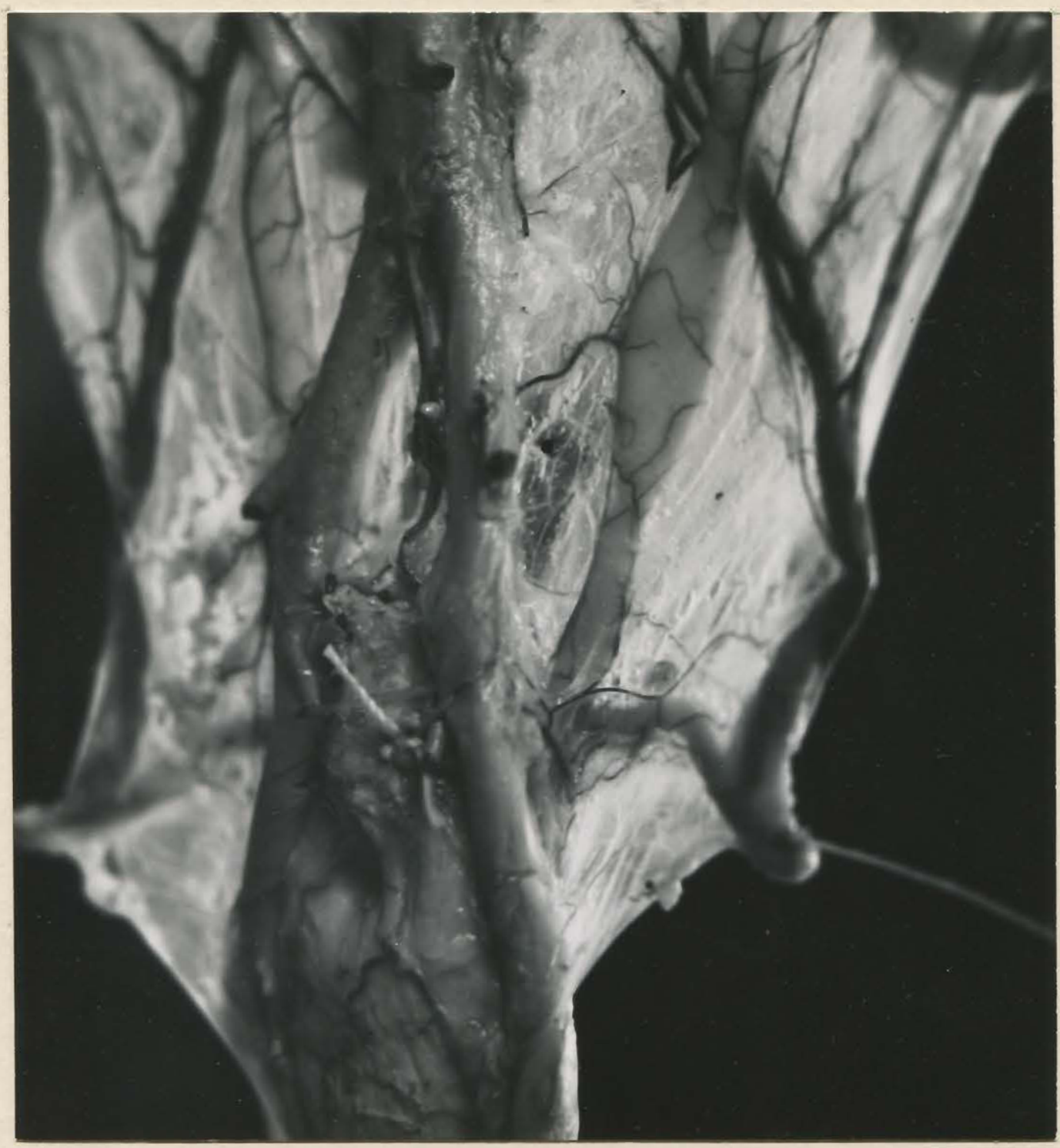

Figure 9. - Male, new-born, lateral aspect. Note lateral approach of inferior vesical artery and branches to posterior aspect of ureter. 


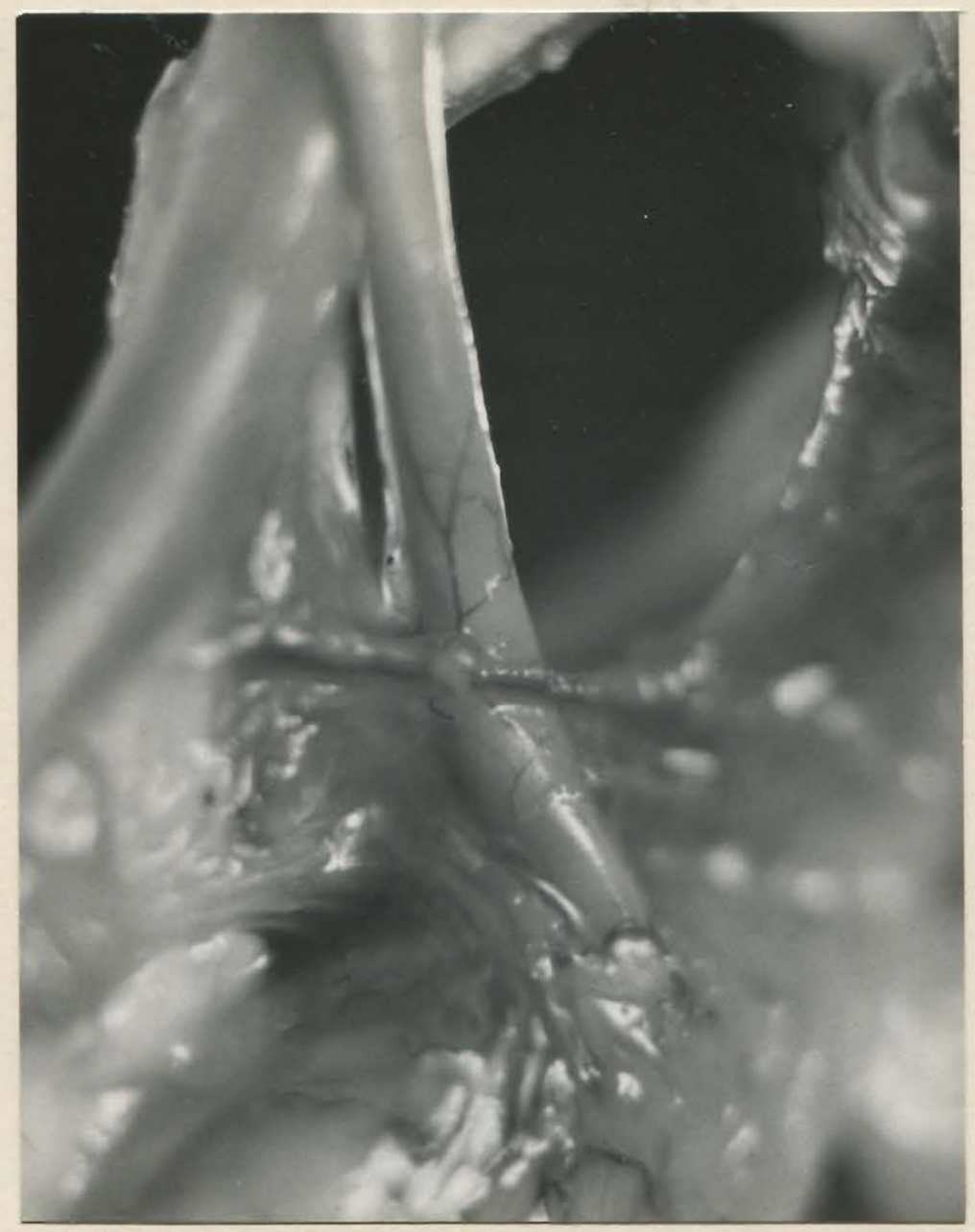

Figure 10 - Female, foetus, lateral anterior aspect. Note uterine artery and small adherent branches to ureter. 


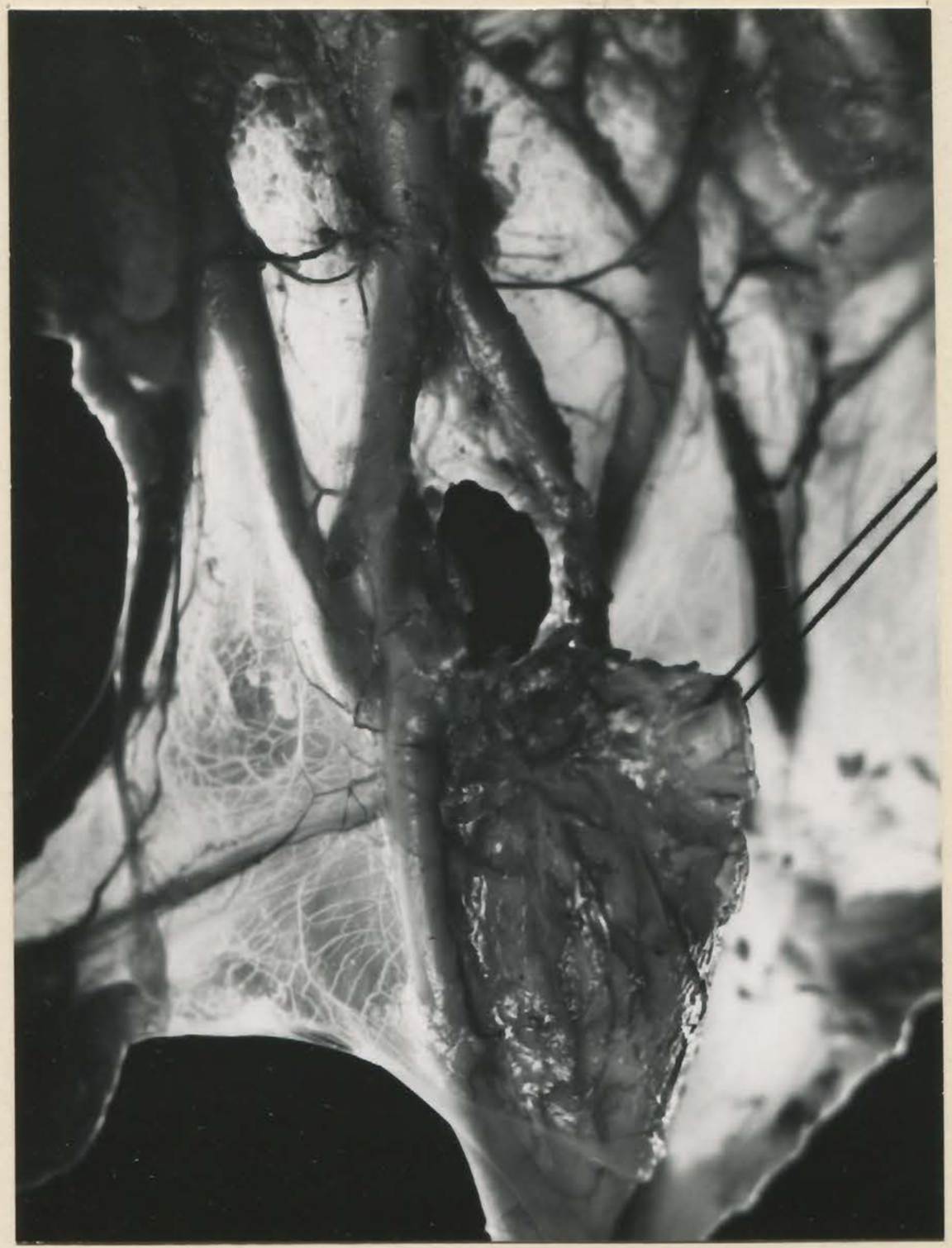

Figure 11 - Male, new-born, posterior aspect. Note periureteral plexus and marked plexus on bladder wall. 


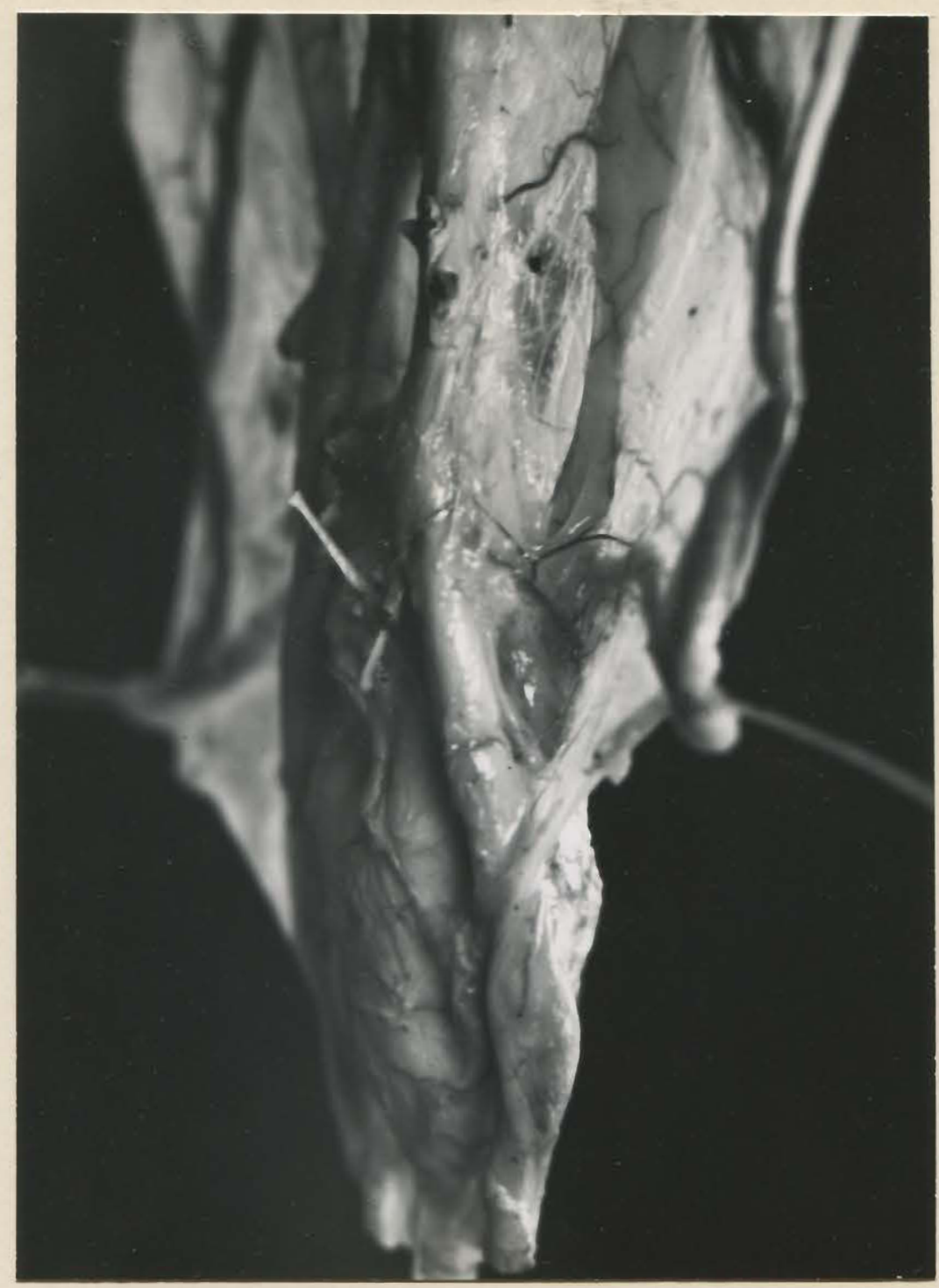

Figure 12 - Male, new-born, lateral aspect. Note lateral approach of inferior vesical artery and branches to posterior aspect of ureter. 


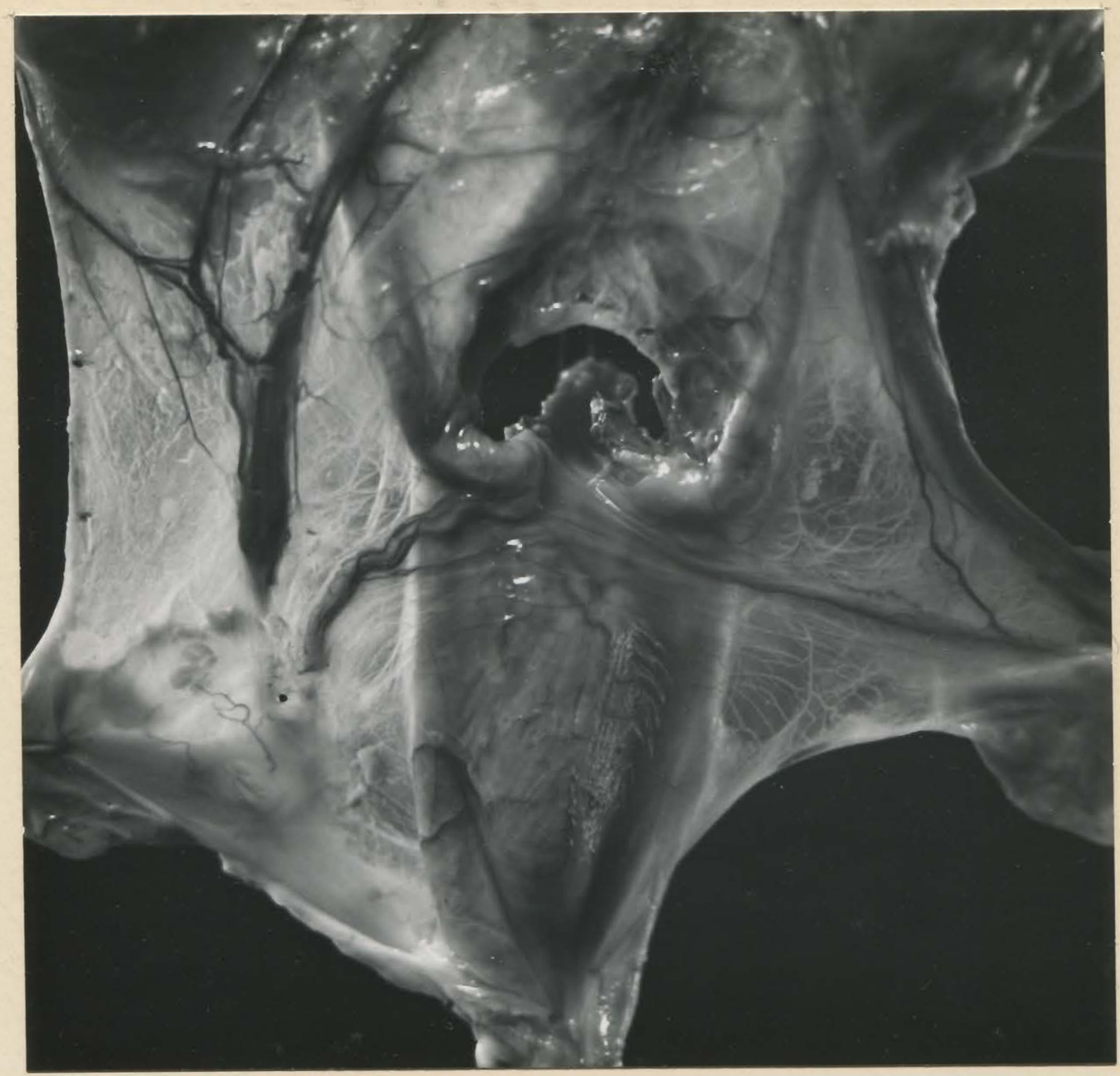

Figure 13 - Male, new-born, anterior aspect. Note arteries from genitalia to lateral side of ureters. Note marked anastomosis across bladder. 


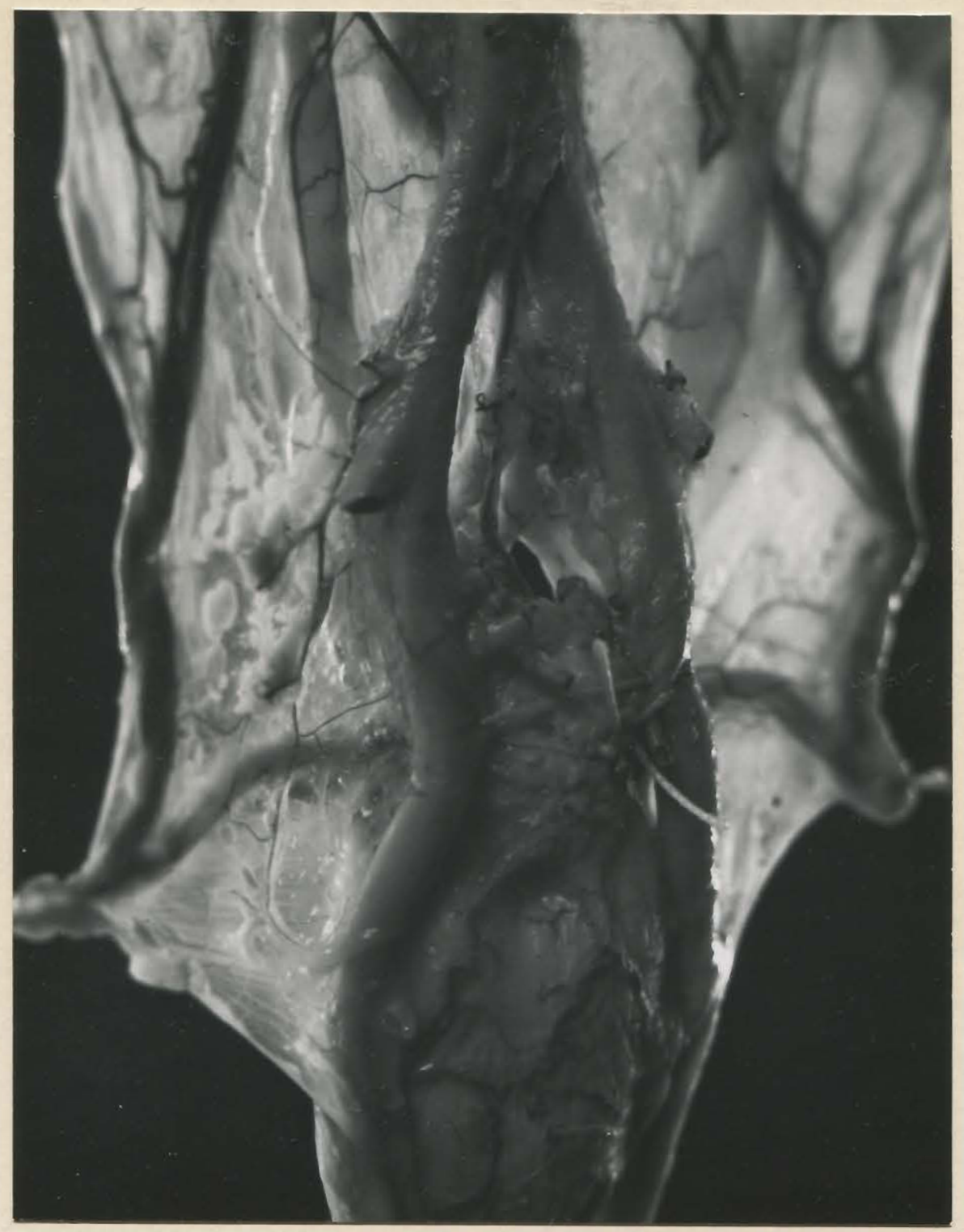

Figure 14 - Male, new-born, lateral posterior aspect. Note rare occcurance of branch from external iliac. 